Illinois State University

ISU ReD: Research and eData

Theses and Dissertations

$10-28-2020$

\title{
Impacts Of Land-Use Change On The Menominee River In Jo Daviess County, Illinois
}

Preston J. Konop

Illinois State University, pjkonop@gmail.com

Follow this and additional works at: https://ir.library.illinoisstate.edu/etd

Part of the Geology Commons, Geomorphology Commons, and the Hydrology Commons

\section{Recommended Citation}

Konop, Preston J., "Impacts Of Land-Use Change On The Menominee River In Jo Daviess County, Illinois" (2020). Theses and Dissertations. 1336.

https://ir.library.illinoisstate.edu/etd/1336

This Thesis is brought to you for free and open access by ISU ReD: Research and eData. It has been accepted for inclusion in Theses and Dissertations by an authorized administrator of ISU ReD: Research and eData. For more information, please contact ISUReD@ilstu.edu. 


\section{IMPACTS OF LAND-USE CHANGE ON THE MENOMINEE RIVER IN JO DAVIESS}

COUNTY, ILLINOIS

\section{PRESTON J. KONOP}

\section{Pages}

This study addresses land-use changes in Jo Daviess County, Illinois, and their effects on the Menominee River. The Menominee River flows north to south through Jo Daviess County, and southern Grant County, Wisconsin. Many of the surrounding properties are agricultural and have undergone developmental and land-use changes that may affect the flood flashiness of the Menominee River. The concern with increasing flood flashiness of the Menominee River include more frequent flooding events, undercutting of riverbanks, and increased amounts of sediment transport from upstream locations into the Mississippi River. Increases in impermeable surfaces have led to greater amounts of runoff during precipitation events causing more sediment to wash into the river. In addition, more intense or longer duration precipitation events will create greater amounts of runoff moving over the landscape and into the Menominee River. Along with the sediment being transported by runoff, the risk for chemical contaminants such as agricultural chemicals, road salt, and automotive fluids increases. Chemicals in runoff water can be transported downstream and pollute drinking water, while sediment loss reduces the amount of cropland within the watershed. Large scale precipitation events also cause more water to flow into the Menominee River rather than infiltrate into the ground, resulting in an increased risk of flood events. Flooding events pose risks to cropland and subdivisions that reside near the Menominee River, which are subject to property or crop damage. 
This thesis works to accomplish three goals. The first is to determine what size clasts are capable of moving downstream with flow, following events resulting in an increase of stream discharge. The second goal of the research is to evaluate the accuracy of discharges that move clast downstream by comparing discharges to a stream that is monitored with a gauge station. This is not a comparison of how sediment and clasts move, rather a comparison of the reaction to recharge events and how discharge changes before and after the event. The final goal of the project is to address how varying weather patterns affect the discharge of the Menominee River and can increase the flashiness resulting in clast movement. 


\title{
IMPACTS OF LAND-USE CHANGE ON THE MENOMINEE RIVER IN JO DAVIESS COUNTY, ILLINOIS
}

PRESTON J. KONOP

\author{
A Thesis Submitted in Partial \\ Fulfillment of the Requirements \\ for the Degree of \\ MASTER OF SCIENCE \\ Department of Geography, Geology, and the Environment \\ ILLINOIS STATE UNIVERSITY
}


Copyright 2020 Preston J. Konop 


\section{IMPACTS OF LAND-USE CHANGE ON THE MENOMINEE RIVER IN JO DAVIESS COUNTY, ILLINOIS}

PERSTON J. KONOP

COMMITTEE MEMBERS:

Lisa Tranel, Chair

Eric W. Peterson

Wondwosen Seyoum 


\section{ACKNOWLEDGMENTS}

I would like to thank Dr. Lisa Tranel for her role as the chair for my thesis committee and for her help in advising and developing the whole thesis project with me. Additionally, I would like to thank Dr. Eric W. Peterson and Dr. Wondwosen Seyoum for serving on my thesis committee. Thank you to my fellow graduate students, Emmett Spooner, Caitlin Noseworthy, and Jack Wassik, for assisting with data collection. Finally, I would like to thank my family and friends for their support throughout my education and completion of my master's thesis.

Thank you!

P.J.K. 


\section{CONTENTS}

Page

ACKNOWLEDGMENTS

TABLES iii

FIGURES iv

$\begin{array}{ll}\text { CHAPTER I: INTRODUCTION } & 1\end{array}$

$\begin{array}{ll}\text { CHAPTER II: METHODS } & 10\end{array}$

$\begin{array}{lc}\text { CHAPTER III: RESULTS } & 18\end{array}$

$\begin{array}{ll}\text { CHAPTER IV: DISCUSSION } & 28\end{array}$

$\begin{array}{ll}\text { CHAPTER V: CONCLUSION } & 37\end{array}$

$\begin{array}{ll}\text { WORKS CITED } & 40\end{array}$

APPENDIX A: SUPPLEMENTARY FIGURES 44 


\section{TABLES}

Table

Page

1. Observed precipitation of most recent rain event (NOAA, 2020) 10

2. Conditions during sampling (NOAA, 2020) 18

3. Average velocity at each location during sampling events 19

4. Discharge at each location based on velocities collected at sampling 20

5. D95 values at each location $\quad 20$

6. Total number of painted tracer clasts found during each sampling event 25

7. Date found and distance traveled of tracer clasts displaced from their starting location 26

8. Discharge and stream height values for the Sinsinawa and Menominee Rivers 29

9. Velocity and discharge of flood events based on Manning's equation 31

10. Manning's equation variable values 


\section{FIGURES}

Figure

Page

1. Inset map of Joe Daviess County, Illinois 4

2. Watershed boundaries of the Menominee and Sinsinawa Rivers 5

3. Field location along North Tranel Road 5

4. Comparison of the field area from 1992 (A.) and 2015 (B.) 7

5. Location 1's clasts before (A.) and after (B.) painting 12

6. Location 1 on 09/15/2019 following a flood event 13

7. Diagram of sampling points for active water depth 15

8. Cumulative probability curves for Location 1

9. Cumulative probability curves for Location 2

10. Cumulative probability curves for Location 3

11. Cumulative probability curves for Location $4 \quad 24$

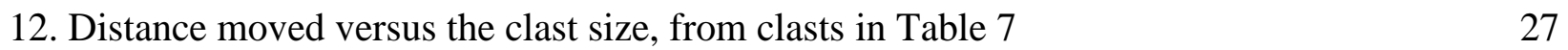

13. Location 1 at the beginning of sampling on 06/14/2019 (A.), 33 and at the end of sampling on 10/19/2019 (B.)

14. Highwater marks and changes to the area surrounding the stream 


\section{CHAPTER I: INTRODUCTION}

An increase in impermeable surfaces including buildings, roads, and structures, is a phenomenon seen around the world as urbanization increases and land use changes to accommodate increasing global populations. However, urban surfaces are not limited to the impermeable surfaces such as roads and buildings. These urban impermeable surfaces also include gardens, lawns, and any other altered surface from its natural state or farmland. It is expected that twothirds of the world's population will live in cities by 2050 (United Nations, 2008). Along with this increase in population there will likely be an increase in infrastructure, in particular, impermeable surfaces. Changes in land use caused by urbanization often lead to increases in flood flashiness by converting natural land-cover to human modified surfaces with lower rates of sediment retention, permeability, and nutrients (Leopold 1968). Urban surfaces provide fast outlets for rainwater due to their inability to allow water to percolate into the subsurface, allowing water to flow faster and more violently into catchments. The faster rates of flow create an environment that favors sediment transport to downstream locations. Urbanization is not the only variable influencing streams; land-use change such as clearing vegetation, logging, agriculture, mining, and grazing land all disturb streams and the landscape (James, 2013). Ultimately, these changes in land-use and urbanization create a greater risk of flooding, flood flashiness, high nutrient levels, and unstable surface water temperatures (Booth, 1991). The increases in urban surfaces and land-use change alone are not the only factors affecting the flashiness of streams. Climate change plays a large role and is expected to escalate the effects of flashiness by increasing the frequency and magnitude of flooding events, and by creating more volatile storm-water runoff (Knox, 1985). Flooding events pose risks to cropland and 
subdivisions that reside near streams and rivers, which are subject to damage during flooding or stream channel migration.

As more water enters streams via overland flow, the materials transported and velocity, or energy, downstream will increase (Dietz and Clausen, 2008). One particular problem caused by this increase is the input of oils, chemicals, and road salt from urban surfaces transported into the streams, thus reducing water quality (Leopold, 1968). Chemicals and dissolved solids in runoff can be transported downstream and pollute drinking water, while sediment loss reduces the amount of viable cropland within the watershed. Nitrogen $(\mathrm{N})$ can contaminate surface water as a result of crop cultivation, burning fossil fuels, and the application and creation of ammonia fertilizers (Bernhardt, 2008). The second problem created by increased stream flow is channel erosion, channel migration into agricultural fields, or bank failures adjacent to structures including roads, bridges, or homes.

Land-use change can negatively impact the water quality of the stream and river systems by increasing suspended sediment loads and nutrients (Neal, 2015). In the region of the Menominee and Sinsinawa Rivers, perennial vegetation was dominant prior to agricultural related land-use change (Knox, 2001). This caused decreases in hydraulic roughness leading to increased runoff and a decrease in infiltration (Morin, 1977). Changes such as this can cause more frequent overflowing of riverbanks and an increase in floodplain sedimentation in river systems (Knox, 2001 and Miller et al. 1993). Ultimately any changes to terrain, vegetation type, soil properties, land-use, or geology can affect the geomorphology of a stream (Knox, 2006). In this particular area agricultural practices have likely impacted local streams and it is likely that climate change has had an increasing impact on watersheds (Tomer et al. 2009). 
This project utilized field observations and natural tracers to understand how a modern river, specifically the Menominee River, reacts to high water and flood events. The watershed of this river drains some areas experiencing new development; however, it lacks stream gauges to monitor stream flow or sediment transport to the Mississippi River. Data collected from June to October of 2019 for the Menominee River, included discharge, flow velocity, and tracer clast movement. During this time, 27 rainfall events occurred, and two of these events caused water to overflow the river's banks. These data were used to understand the potential impacts of flash floods, including the flood discharge and efficiency of to erode and transport sediments. The strength of the stream and flood discharge were determined based on active channel flow and predicting flood channel flow from high water levels, channel bedload, and movement of tracer clasts.

Study Site:

This study will address the flashiness of the Menominee River in Jo Daviess County, Illinois, and how the flashiness affects the Menominee River. Jo Daviess County lies in the Wisconsin Driftless area of Illinois, a portion of the state that remained untouched by glaciers during the Illinois and Wisconsin glaciations (Figure 1) (Reinertsen, 1992). The Menominee River flows north to south through primarily agricultural land in Jo Daviess County, Illinois and southern Grant County, Wisconsin, this river and the Sinsinawa River have watersheds that flow to the Mississippi River (Figure 2). At the field location the Menominee River flows through pastureland, and a small subdivision; the area around the field site also includes agricultural fields (Figure 3). The Menominee River flows south into the Mississippi River near East Dubuque, Illinois. The lack of glacial influence allowed rivers in this region to create valleys and hills in bedrock primarily consisting of Ordovician and Silurian limestones and dolomites; some 
sandstone, shale, and siltstone layers within Ordovician age rocks are also present (Reinertsen, 1992). Streams in this region have channels composed of bedrock or sandy gravels, with a bedload that consists of sand, granules, pebbles, cobbles, and boulders. The bedload material, excluding sand which has loess origins, originates from local bedrock exposures (Knox, 1983).

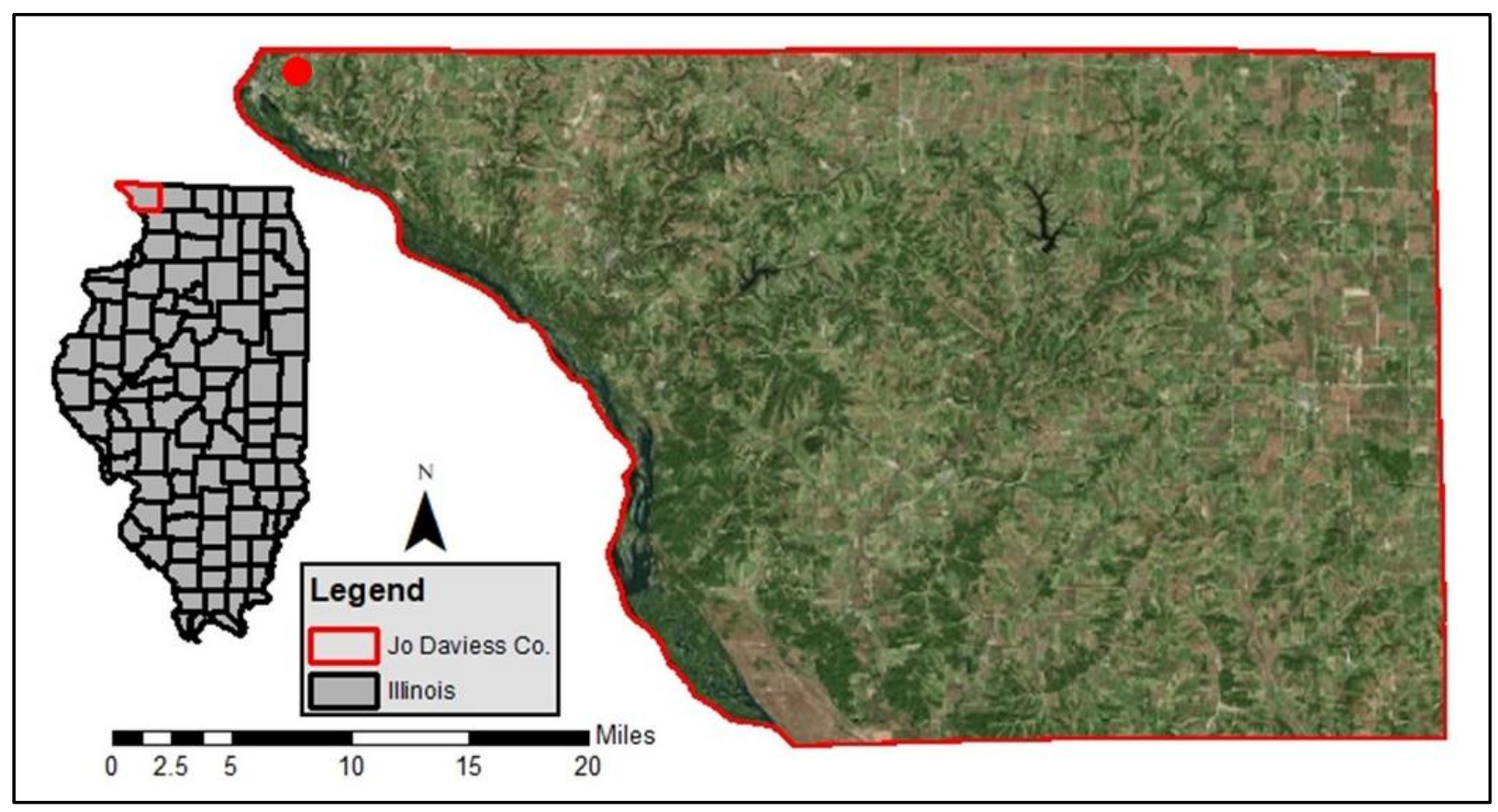

Figure 1: Inset map of Joe Daviess County, Illinois. The field area is identified by the red dot in the northwest portion of the county. 


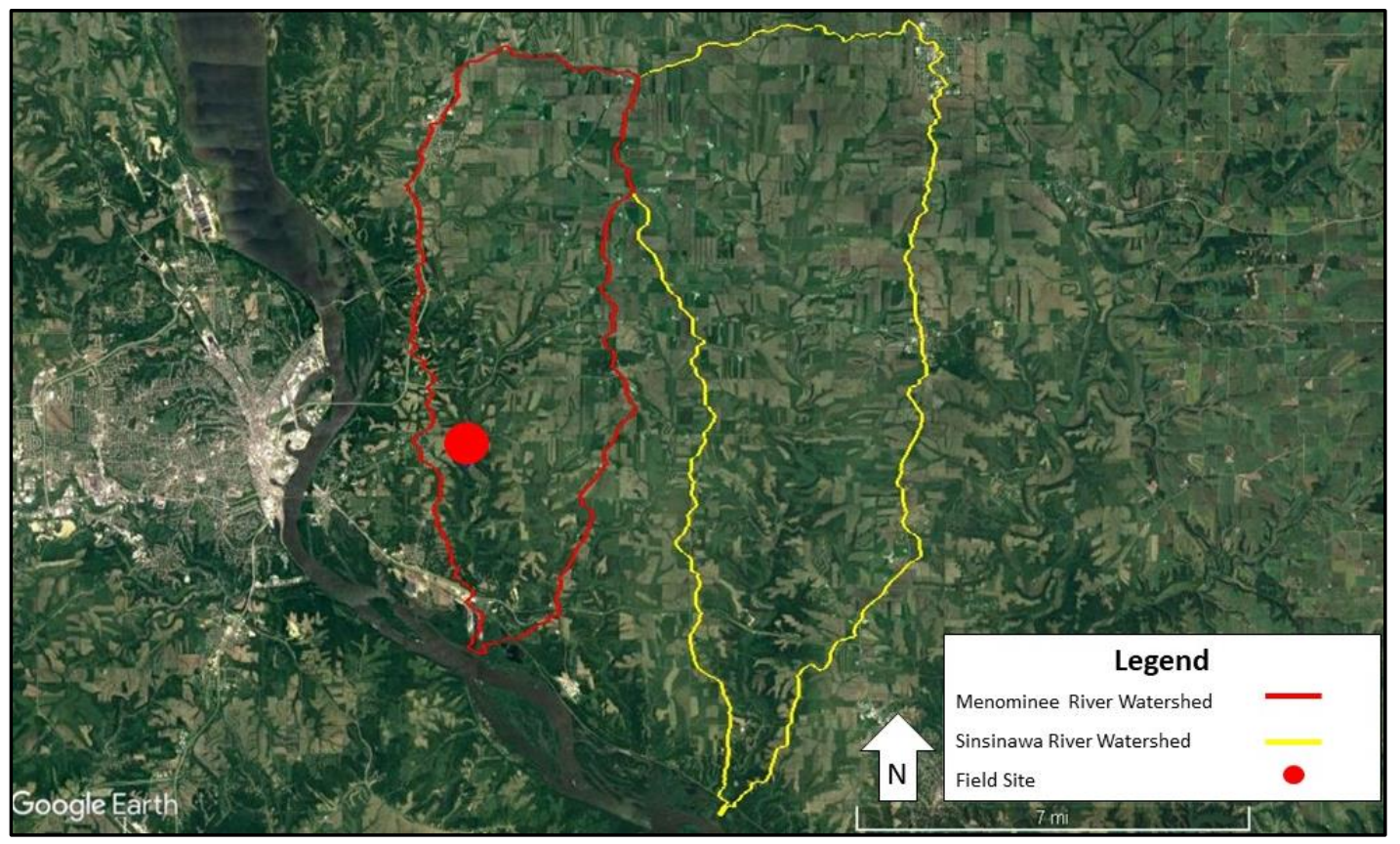

Figure 2:Watershed boundaries of the Menominee and Sinsinawa Rivers. The field site is located at the red dot.

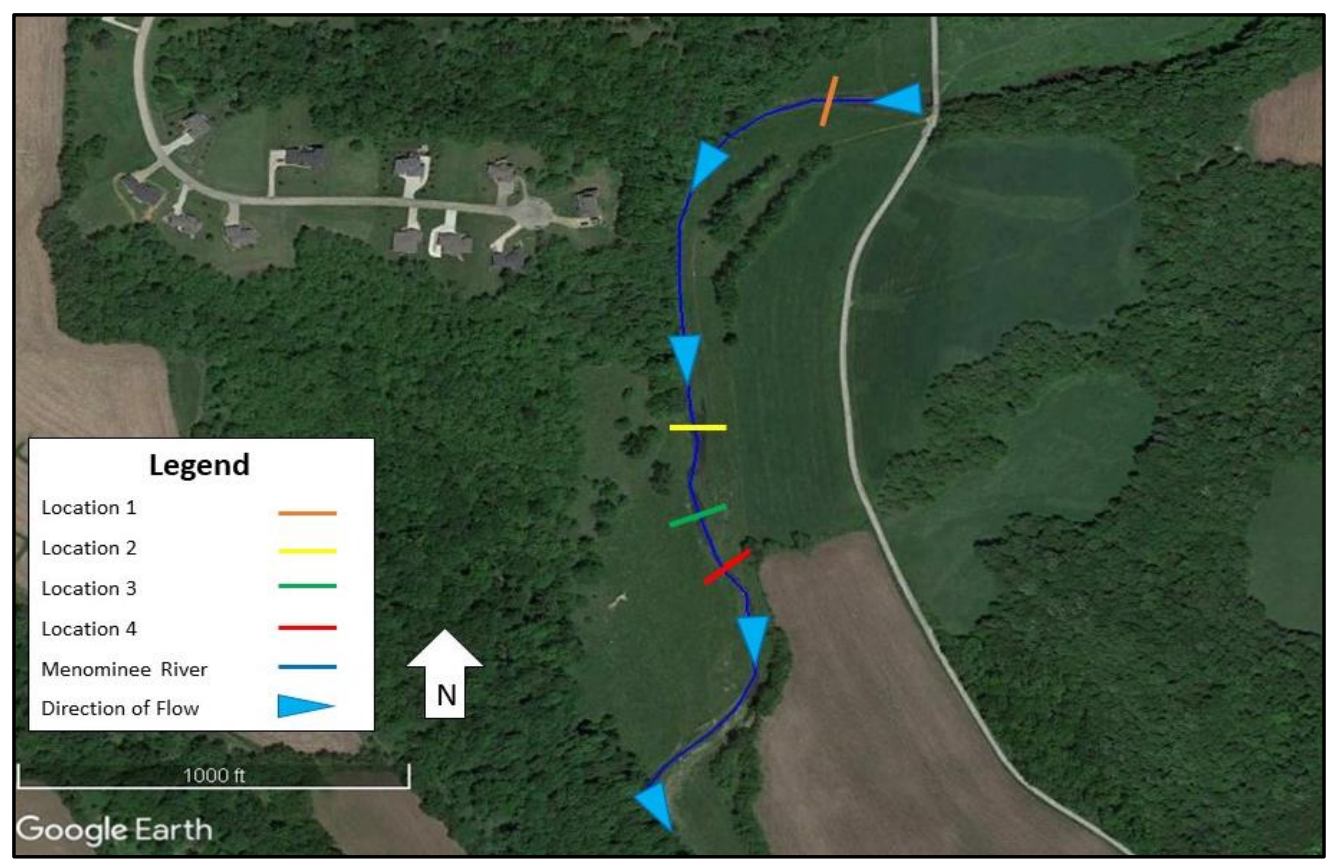

Figure 3: Field location along North Tranel Road. Cross-section locations are indicated by colored lines. 
The area surrounding Jo Daviess County has undergone extensive anthropogenic related change and events. Geologically the area is associated with the Wisconsin driftless area, an area that was unglaciated and known for steep and moderate sloped uplands with narrow valley floors (Knox, 1999). The bedrock in Jo Daviess County is composed mainly of Ordovician and Silurian age carbonate rocks which are covered by unconsolidated deposits ranging from 0 to 24.6 feet (Panno, 2017). Additionally, Jo Daviess County lies within one of the five karst zones in Illinois, and karst features are present in an outcrop at the field site (Panno, 2015). The steep slopes covered with less than 3.28 feet of loess paired with the small size of watersheds in this area potentially contributes to be more flood peaks from common small rainstorms.

During the late 1800 's and early 1900 's the flood rates were five to six times greater in magnitude than pre-agriculture floods (Knox, 1999). This accelerated runoff caused severe soil erosion, 3.54-6.30 inches of topsoil loss, over the past 170-220 years of agriculture (Knox, 1999). These agricultural practices increase and accelerate the amount of runoff and soil erosion as a result of cultivation. The process of cultivating land leaves bare soil exposed to destructive forces such as precipitation. Bare soil also provides a low hydraulic friction pathway for overland flow that minimizes infiltration (Wauchope, 1999). This occurs heavily during the early growing season when there is no canopy from crops (Knox, 2001). In particular, the force of water traveling at velocities up to $29.53 \mathrm{ft} / \mathrm{s}$ and striking the bare ground can cause soil aggregates to break apart and reduce infiltration by plugging pathways for water to infiltrate (Storey, 1964).

Many of the surrounding properties are farmland with dairy and agricultural uses, which accelerate runoff and erosion compared to natural landscapes. The landscape's sensitivity to modern hydrologic processes is high given the landscape's agricultural use, which makes it more 
susceptible to sediment transport due to the lack of land cover (Knox, 2001). Some of the surrounding land has undergone developmental and land-use changes that may affect the flood flashiness of the Menominee River. A large subdivision on Joyce Court, seen in Google Earth imagery, has been built between 1993 and 2019 that resides along the west bank Menominee River (Figure 4). In addition to this subdivision there are other structures that were built along the river to the north. East of the Menominee River at this location there are agricultural fields. The increase of urban impermeable surfaces, including the aforementioned developments has likely led to more aggressive overland flow through drainages into the Menominee River. These drainages may run through agricultural land, degrading the landscape through erosion. This will result in larger amounts of suspended bedload and sediment transport locally into the Menominee River, and ultimately into the Mississippi River.

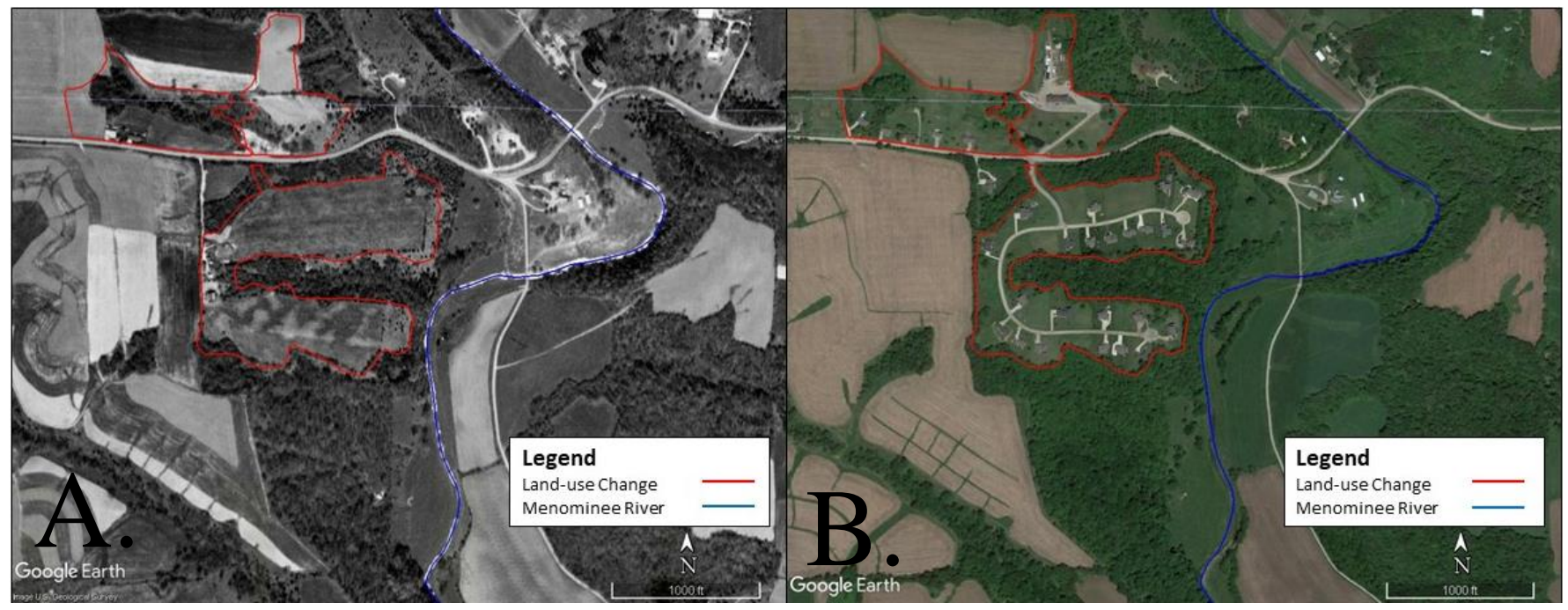

Figure 4: Comparison of the field area from 1992 (A.) and 2015 (B.). This image shows how develop increased from 1992 to 2015. 
Sources of Nitrogen (N) and contaminants feed into the Menominee River, which empties into the Mississippi River and ultimately, the Gulf of Mexico. The increased amount of run-off is a likely a contributor to the nitrification and seasonal hypoxia in the Gulf of Mexico (Alexander, 2007). This increase in run-off can be monitored by sedimentation rates and clast movement in streams. Monitoring the meander of a stream over time can identify how the energy in a stream has dissipated or increased as development occurred. In addition to monitoring stream meander, patterns in sedimentation rates can be used to determine changes to a stream over time (Walling and He 1998). Historically, events surrounding agricultural development have often led to greater amounts of sedimentation in rivers, resulting in sediment buildup, and ultimately, excessive flooding events in lower areas (Simon and Rinaldi 2006). Monitoring changes in sedimentation rates along with stream meander can be used to predict future events and change to rivers and their surroundings.

Addressing the change in land-use of a small area over time can provide the basis for rate of urbanization and how it affects the flashiness of streams. Monitoring one stream's changes can provide data that can be applied to similar streams in different watersheds, allowing predictions to be made on the impacts of development and land-use change. These data can be used to identify when streams begin to become more erosive as a result of urbanization and changes in land-use. Understanding local streams, like the Menominee River in Jo Daviess County, Illinois, can help in determining the overall sedimentation and flashiness of downstream locations caused by urbanization and land-use change. For this system, downstream locations such as the Mississippi River and the Gulf of Mexico may be affected by urbanization and landuse change upstream. When considering other small systems and tributaries to the Mississippi River that are undergoing land-use change, sedimentation and flood flashiness are important 
factors to monitor as development progresses. This can help in the creation of management plans to mitigate sedimentation and flooding of downstream locations. Quantifying changes to these systems and determining the full impact of flash floods is challenging to define in rivers and streams that do not have permanent stream gages. Observations of the river channel characteristics and transported sediment provide methods to calculate these impacts after flood events.

Research Questions:

This thesis works to accomplish three goals. The first is to determine what size clasts are capable of moving downstream with flow, following events resulting in an increase of stream discharge. The second goal of the research is to evaluate the accuracy of discharges that move clast downstream by comparing discharges to a stream that is monitored with a gauge station. This is not a comparison of how sediment and clasts move, rather a comparison of the reaction to recharge events and how discharge changes before and after the event. The final goal of the project is to address how varying weather patterns affect the discharge of the Menominee River and can increase the flashiness resulting in clast movement. 


\section{CHAPTER II: METHODS}

The Menominee River was observed at four locations adjacent to the Joyce Court development. One cross-section was upstream of a bedrock reach along the west side of the river just east of the subdivision. The other three sites were located downstream of this bedrock reach. The downstream sites were 36-450 yards apart. Data were collected on six different occasions, before and after major precipitation events from June through October of 2019. There was a total of six sampling events when measurements and field observations were taken (Table 1).

\begin{tabular}{|c|c|c|}
\hline Sampling Date & Most Recent Rain Event & $\begin{array}{c}\text { Observed Precipitation } \\
\text { (inch) }\end{array}$ \\
\hline $06-14-2019$ & $06-13-2019$ & 0.23 \\
\hline $07-27-2019$ & $07-19-2019$ & 1.10 \\
\hline $09-01-2019$ & $08-21-2019$ & 0.18 \\
\hline $09-15-2019$ & $09-12-2019$ & 2.41 \\
\hline $10-19-2019$ & $10-06-2019$ & 0.58 \\
\hline
\end{tabular}

Table 1: Observed precipitation of most recent rain event. This data shows the amount of rain prior to sampling events (NOAA, 2020).

The stream bed slope was calculated using a laser rangefinder and basic trigonometry. While standing at the center of each cross-section location a point was shot upstream to the active water depth and then again downstream to the active water depth. The points gathered with the range finder provide a total length and change in height, or rise over run, between the upstream and downstream locations. The degree of the slope was then calculated using the tangent equation.

Tracer clasts were used to monitor the strength of the channel's flow over the study period (Figure 5). These clasts were monitored for movement during each field outing. Three 
transects were chosen for painted tracer clasts. At each of these transects 100 clasts were chosen at random, directly from the streambed (Goode, 2010). The clast sizes were identified using a gravelometer, then placed on the bank to dry before spray painting them with three different colors of Rustoleum Implement Paint, with each color corresponding to a cross section location. Clasts were only painted on the first sampling event. Once the clasts were dried, they were painted with a water-resistant implement paint, allowed to dry again, and then randomly scattered along the transect line between the stream's banks. After the first sampling event clast counts were done to check the average clast size along cross sections and check for the painted clasts. This was done by picking 100 clasts at random from the transect line, at each location, and recording their size. During each of the field outings painted clasts were searched for and if found the size and distance downstream traveled was measured. Clasts that had moved were identified as being downstream from the original transect line. When found, the distance along the streambed from the starting transect was recorded along with the tracer clast's size. If the clast was within 8 feet of the starting transect, the distance was measure with a tape measure/stadia rod. If the clasts moved more than 8 feet distance downstream from the transect, GPS coordinates were used to measure the distance downstream from the transect. These measurements, including the painting of clasts, were done on June $14^{\text {th }}$, July $27^{\text {th }}$, September $1^{\text {st }}$, September $15^{\text {th }}$, and October $19^{\text {th }}$ of 2019. 


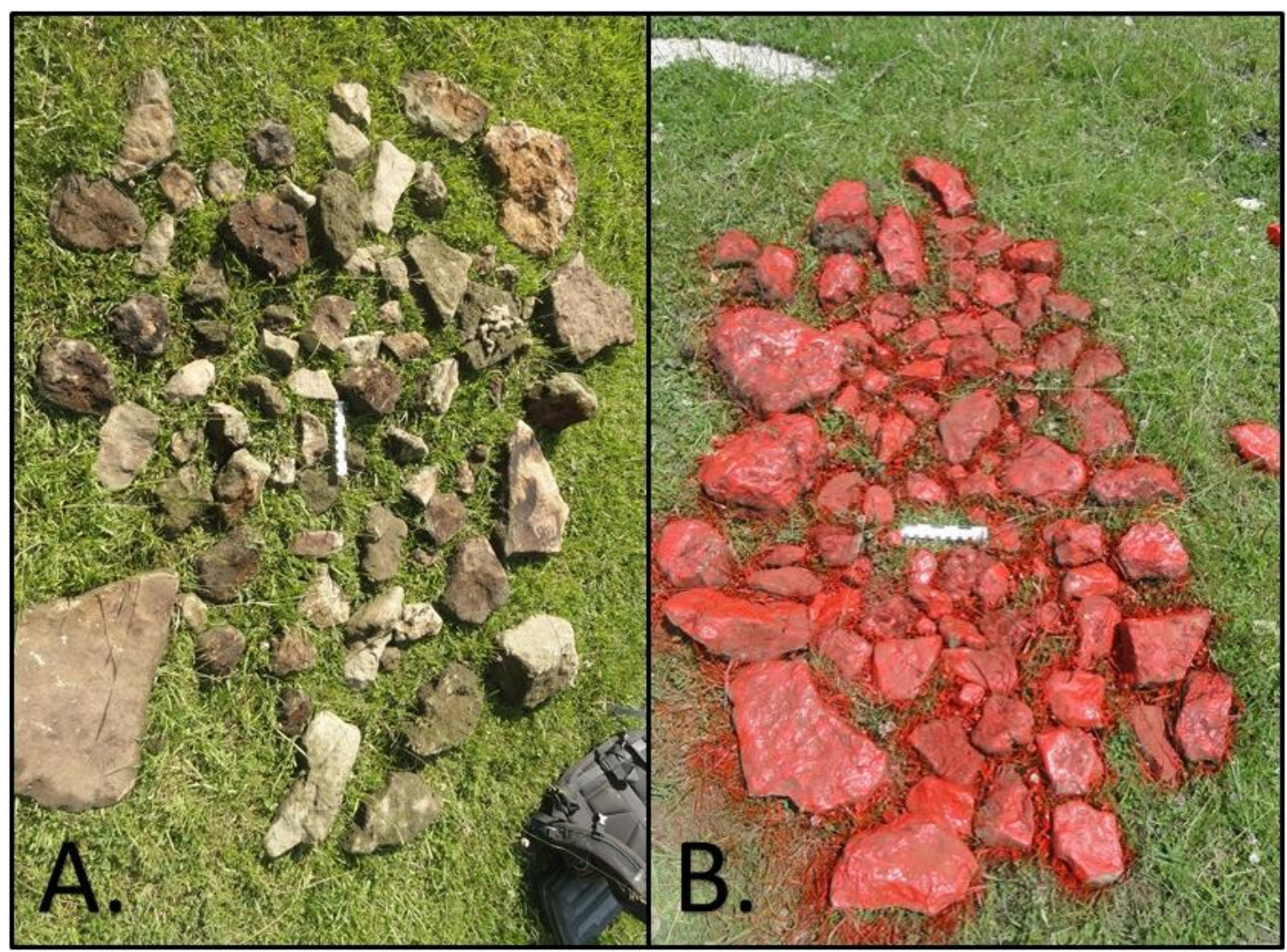

Figure 5: Location 1's clasts before (A.) and after (B.) painting.

The clast sizes collected during the field outings were then used to create a cumulative percent curve of clast sizes at each transect. The D95 values were determined using cumulative probability curves created on MATLAB software. The clast size values were entered into the software and logarithmic graphs were created and used to find the D95 value or clast size value where $95 \%$ of the clasts were smaller than that value. This process was also used to determine the D50 and D80 values.

Stream cross-sections were measured in transects from bank to bank to determine active flow area, bank-full area, and overbank flood event areas based on high-water mark to highwater mark. The data after major flood events were collected when water levels returned to safe levels after storm events. Measurements for depth and velocity were taken at equal intervals 
across stream cross sections (Whiting, 1999). When the stream was at base flow, a measuring tape was strung bank to bank, and depth measurements were taken at intervals of 0.25 meters from bank to bank and from the water surface to the stream bed using a stadia rod. After major flood events, high-water indicators were identified based on stain lines, vegetation, debris, and other subtle indicators of high-water (Wohl, 2005; Whiting, 1999). If high-water marks were present, mason line was strung between high-water marks and flood depth was measured from the stream bed to the mason line (Figure 6). Highwater marks were measured at 1.64 foot intervals across the transects of the stream. On some occasions, the stream was actively flowing at a bank-full or flood stage and were considered an active high-water measurement. Not all flood events were measured for velocity and cross-section as a safety precaution.

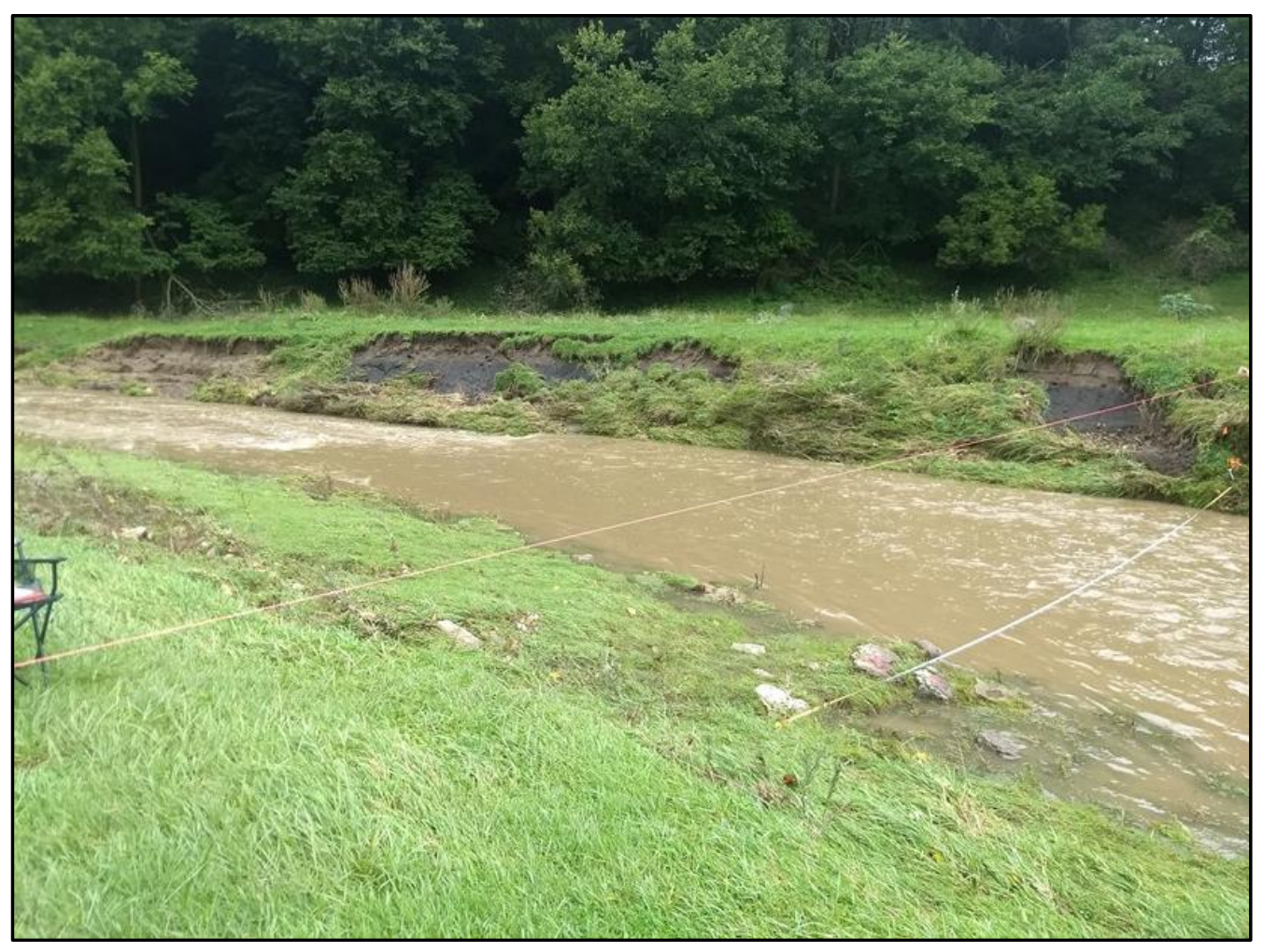

Figure 6: Location 1 on 09/15/2019 following a flood event. Note the thin mason line running out of frame left to out of frame right. This indicates the highwater mark. 
Velocity was measured with each stream cross-section measurement, but only active flow was measured for depth in each subsequent visit. The measurements for velocity were taken at the same equal intervals as active stream depth along the length of the stream in the study area (Whiting, 1999). At each 0.82 foot mark velocity was taken using a Global Water Flow Probe. The flow probe depth was determined by the depth of active water from the stadia rod and was held in active water at a depth determined by the following equation:

$$
\text { Sensor Depth }=\frac{(D * 0.6)}{10}
$$

This equation was used because the stadia rod was marked in quarter inch increments and the flow probe was marked in tenths of an inch. In order to use the instruments, the collected data needed to be converted so the next instrument could be used. In this equation, the Sensor Depth is the depth of the velocity meter from the surface and $D$ is the depth of the stream at the 0.82 foot transect. This calculation was required due to differences in incrementation on the stadia rod and the velocity meter and to measure the velocity using standard procedures at 6 tenths depth (USGS “6 tens method"). After the depth was determined for the sensor, it was held at that depth until the sensor stabilized to the velocity of the stream.

After field measurements were taken, the data were compiled into Excel to calculate the cross-sectional area and discharge. Metric units were converted to imperial units, due to the availability of instruments and to compare to a similar gaged river in the region. In order to calculate the cross-sectional area; the following equation was used for active and bank-full measurements: 


$$
\text { Stream Area }=\left(\frac{L_{3}-L_{1}}{2}\right) * D_{2}+\cdots+\left(\frac{L_{m}-L_{o}}{2}\right) * D_{n}
$$

This equation was done for each point across the stream transect in order to determine the area of the stream (Figure 7).

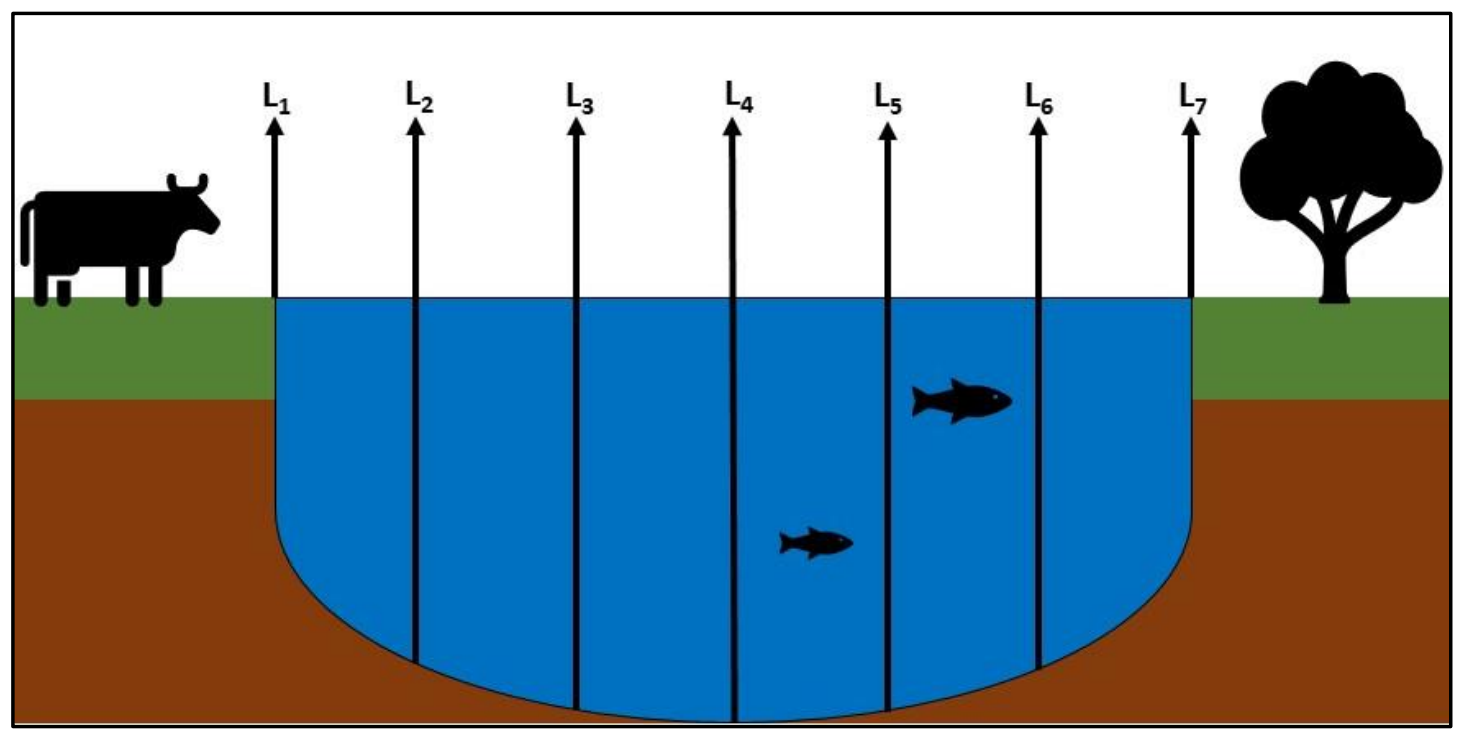

Figure 7: Diagram of sampling points for active water depth. These values were measured at quarter meter intervals and then used to calculate stream area.

These two equations allowed calculation of area for each channel segment between each measurement along the cross section taken in the field. $L_{l}$ indicates the length away from the starting bank and is subtracted from the $L_{3}$ value. The $L_{3}$ value is the second measurement away from the $L_{1}$ value and is further from the starting bank. In summary the $L_{1}$ and $L_{3}$ values are every other measurement for the length of the cross-section. The new $L$ value is then divided by two and multiplied by the $D_{2}$ value. The $D_{2}$ value is the depth of the stream at the $L_{2}$ measurement, the $L_{2}$ measurement lies in between $L_{3}$ and $L_{1}$ along the cross-section's length. When calculating the active water areas, the lengths are subtracted from every other measurement location to account 
for irregularities in the stream bed. Once these calculations have been made for each measurement point along the cross-section transect, they are then added together to calculate the total area of the stream at that transect.

In order to determine the discharge of the Menominee River the values calculated from the Stream Area equation and the values collected in the field for velocity were used. The crosssectional area values and velocity values were then used in the following equation:

$$
\text { Discharge }=V * A
$$

This equation uses the $V$ for velocity collected in the field using the sensor depth equation and value read from the Global Water Flow Probe. The area $A$ value is the value determined from the stream area equation. After determining the discharge for each segment along the stream transect the total discharge was calculated. This provides the average discharge for each sample site along the Menominee River field area.

In addition to calculating the D95 discharge, the velocity required to move the D95 clasts was also calculated. In order to calculate this value, the following equation was used (Costa, 1983):

$$
v_{b}=0.18 * d^{0.487}
$$

This calculation provides the velocity at the bed when D95 sized clasts will move. The $v_{b}$ value was calculated in metric units and then was converted from metric to standard. In this equation the 
0.18 value is a standard. The $d$ is the largest clast size indicated by the D95 value. Once this equation has been completed the conversion to standard can be completed.

After determining the values from the previous equations and taking measurements in the field the Manning's equation was used to determine the Manning's coefficient and flood velocity. This provides an estimation of the max velocity during flood events and can also be used to calculate the flood discharge. The Manning's equation used for these calculations is:

$$
n=\frac{\left(1.49 * R^{0.66} * S^{0.5}\right)}{V}
$$

In this equation $n$ is the Manning's roughness coefficient which is solved for by using four variables. The first is 1.49 which is a constant for unit conversion for standard increments (feet and inches). Next the $R$ indicates the hydraulic radius of the active stream or its channel geometry from the wetted perimeter and depth at varying points along the stream's cross-section. The $S$ variable is the slope of the streambed at each of the four transects. The final variable $V$ is the average velocity of the stream at the transect. These variables provide the basis for determining the roughness coefficient and can be used to determine the highwater velocity of the river. 


\section{CHAPTER III: RESULTS}

The sampling dates (Table 2) were conducted at varying points throughout the summer and fall seasons. The dates chosen for sampling were after major rain events when the Menominee River had returned to a safe level for measurements to be taken. Toward the end of the sampling period there were more frequent rain events that caused severe flooding to the surrounding area and caused the Menominee River to exceed bank-full conditions. While taking measurements in the stream, highwater marks were determined by brush and debris that had been moved by the stream. Following major flood events, the overbank changes in the width and streambed became apparent (Appendix A).

\begin{tabular}{|c|c|c|}
\hline $\begin{array}{c}\text { Sampling } \\
\text { Date }\end{array}$ & Conditions at Sampling & $\begin{array}{c}\text { Number of Rain } \\
\text { Events Between } \\
\text { Sampling }\end{array}$ \\
\hline $06-14-2019$ & Base flow & 3 \\
\hline $07-12-2019$ & Base flow & 4 \\
\hline $07-27-2019$ & Base flow & 1 \\
\hline $09-01-2019$ & $\begin{array}{c}\text { Base flow with highwater } \\
\text { stain. }\end{array}$ & 8 \\
\hline $09-15-2019$ & Bank-full. & 3 \\
\hline $10-19-2019$ & Base flow & 8 \\
\hline
\end{tabular}

Table 2: Conditions during sampling. Along with number of rain events between sampling (NOAA, 2020). 
The average velocity of the Menominee River was recorded in the active channel during each sampling event, some of these values were recorded during or shortly after highwater events. The values for the average velocity at each field site were determined from the velocity values recorded across each transect. Each transect displayed varying average velocities as a result of the size of the transect and the bed material (Table 3).

\begin{tabular}{|c|c|c|c|c|c|}
\hline Location & $\begin{array}{c}\mathbf{0 6 / 1 4 / 2 0 1 9} \\
\text { Velocity (ft/s) }\end{array}$ & $\begin{array}{c}\mathbf{0 7 / 2 7 / 2 0 1 9} \\
\text { Velocity (ft/s) }\end{array}$ & $\begin{array}{c}\mathbf{0 9 / 0 1 / 2 0 1 9} \\
\text { Velocity (ft/s) }\end{array}$ & $\begin{array}{c}\mathbf{0 9 / 1 5 / 2 0 0 1 9} \\
\text { Velocity (ft/s) }\end{array}$ & $\begin{array}{c}\mathbf{1 0 / 1 9 / 2 0 1 9} \\
\text { Velocity (ft/s) }\end{array}$ \\
\hline $\mathbf{1}$ & 0.563 & 0.411 & 0.371 & 1.299 & 0.557 \\
\hline $\mathbf{2}$ & 0.355 & 0.227 & 0.228 & 0.611 & 0.460 \\
\hline $\mathbf{3}$ & 0.411 & 0.333 & 0.312 & 0.335 & $\mathrm{~N} / \mathrm{D}$ \\
\hline $\mathbf{4}$ & 0.921 & 0.674 & 0.629 & 0.914 & 1.430 \\
\hline \hline
\end{tabular}

Table 3: Average velocity at each location during sampling events. On 10/19/2019 Location 3 did not receive measurements due to weather concerns. This cell is filled in with "No Data" (N/D).

The velocity values that were determined from field measurements and calculations were then used to determine stream discharge. Using the calculated velocity values for each transect discharge was calculated for the four sampling locations at each sampling event. These velocity values provided three baseflow discharge values and two highwater discharge values that show the seasonal changes of the baseflow discharge at different times during the sampling period and following weather events (Table 4). 


\begin{tabular}{|c|c|c|c|c|c|}
\hline Location & $\begin{array}{c}\mathbf{0 6 / 1 4 / 2 0 1 9} \\
\text { Discharge } \\
\left(\mathbf{f t}^{\mathbf{3}} / \mathbf{s}\right)\end{array}$ & $\begin{array}{c}\mathbf{0 7 / 2 7 / 2 0 1 9} \\
\text { Discharge } \\
\left(\mathbf{f t}^{\mathbf{3}} / \mathbf{s}\right)\end{array}$ & $\begin{array}{c}\mathbf{0 9 / 0 1 / 2 0 1 9} \\
\text { Discharge } \\
\left(\mathbf{f t}^{\mathbf{3}} / \mathbf{s}\right)\end{array}$ & $\begin{array}{c}\mathbf{0 9 / 1 5 / 2 0 0 1 9} \\
\text { Discharge } \\
\left(\mathbf{f t}^{\mathbf{3}} / \mathbf{s}\right)\end{array}$ & $\begin{array}{c}\mathbf{1 0 / 1 9 / 2 0 1 9} \\
\text { Discharge } \\
\left(\mathbf{f t}^{\mathbf{3}} / \mathbf{s}\right)\end{array}$ \\
\hline 1 & 38.00 & 18.51 & 15.69 & 75.89 & 41.15 \\
\hline 3 & 24.19 & 15.71 & 15.33 & 68.96 & 35.75 \\
\hline 4 & 21.17 & 17.24 & 15.56 & 61.96 & $\mathrm{~N} / \mathrm{D}$ \\
\hline
\end{tabular}

Table 4: Discharge at each location based on velocities collected at sampling. On 10/19/2019 no data were collected at Location 3. The 06/14, 07/27, and 09/01 2019 events are considered baseflow while the 09/15 and 10/19 2019 dates are highwater values.

When analyzing the discharge values, it should be noted that the discharge value decreases at Location 2. This means that there is a loss of water from the active stream between location 1 and this location.

The data collected on September $15^{\text {th }}, 2019$, were considered high water values as the river was exceeding bank-full characteristics and measurements from prior sampling events.

From these velocity values the discharge for each sampling event was calculated and the average discharge for each transect was determined (Table 4).

\begin{tabular}{|c|c|c|c|c|}
\hline Transect & $\begin{array}{c}\text { Average D95 Size } \\
\text { (inch) }\end{array}$ & $\begin{array}{c}\text { Average D95 } \\
\text { Velocity (ft/s) }\end{array}$ & $\begin{array}{c}\mathbf{0 9 / 1 5 / 2 0 2 0} \\
\text { Bankfull D95 } \\
\text { Discharge (ft/s } \mathbf{s}^{\mathbf{3}} \text { ) }\end{array}$ & $\begin{array}{c}\mathbf{0 9 / 1 5 / 2 0 2 0} \\
\text { Highwater D95 } \\
\text { Discharge (ft } \mathbf{3} / \mathbf{s} \text { ) }\end{array}$ \\
\hline 1 & 6.654 & 8.887 & 381.8 & 2217 \\
\hline 2 & 8.110 & 9.778 & 872.1 & 2521 \\
\hline 3 & 6.942 & 8.935 & 403.7 & 1364 \\
\hline 4 & 6.667 & 8.742 & 183.0 & 1663 \\
\hline
\end{tabular}

Table 5: D95 values at each location. This includes the D95 average clast size, velocity, and discharge required to move $95 \%$ of the clasts present in the stream. 

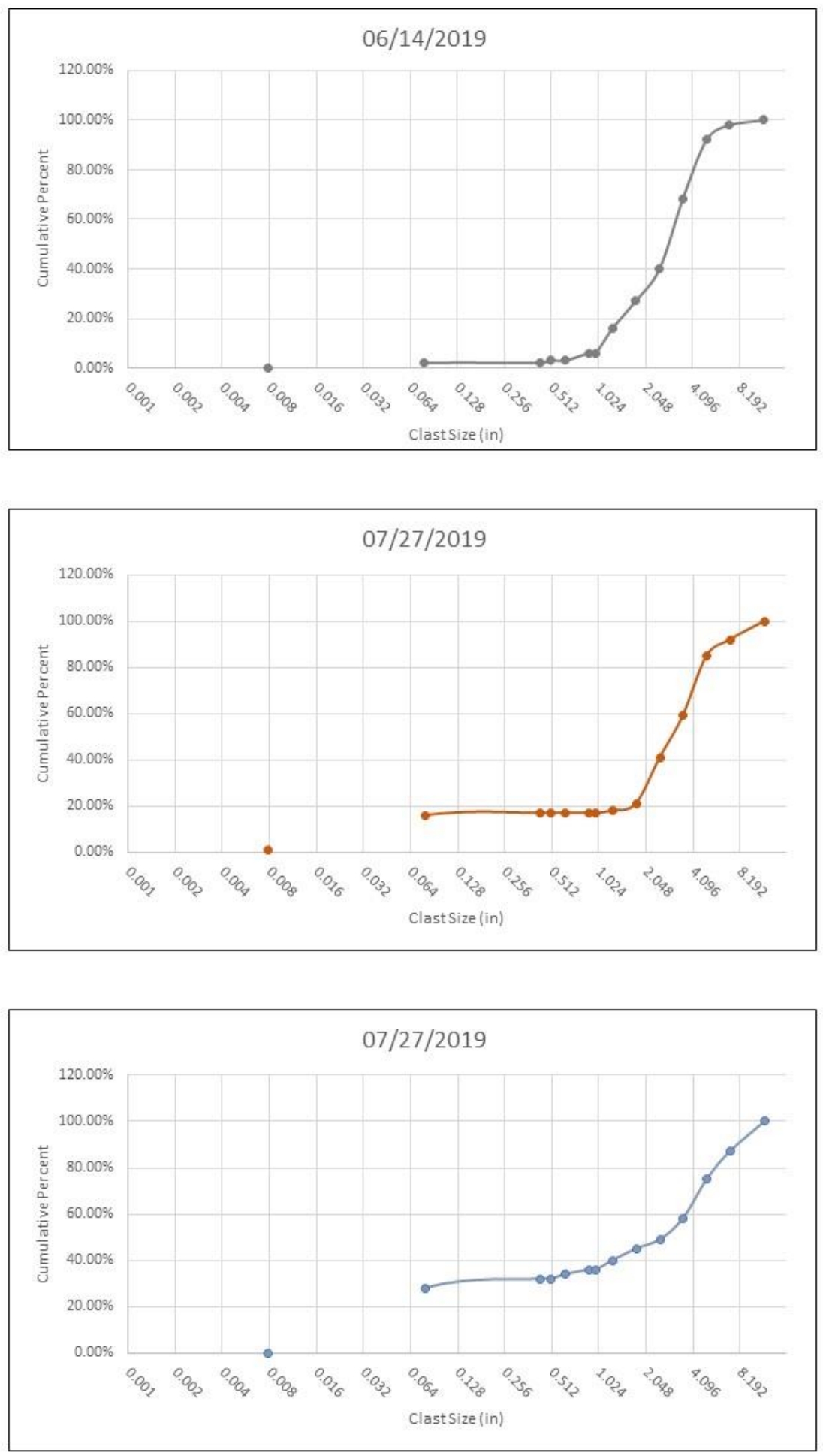

Figure 8: Cumulative probability curves for Location 1. Each of the three sampling dates for clast counts are represented. 

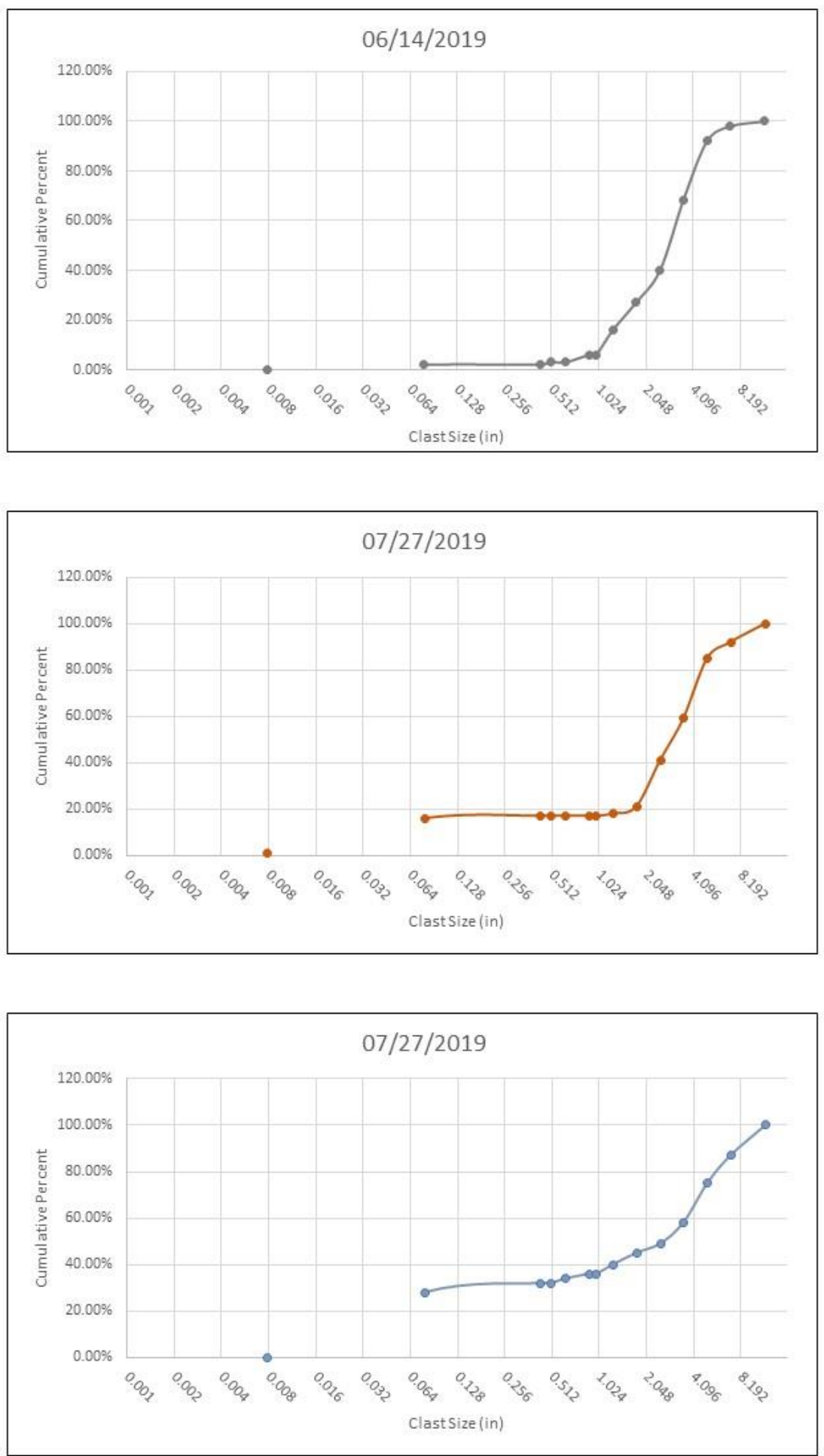

Figure 9: Cumulative probability curves for Location 2. Each of the three sampling dates for clast counts are represented. 

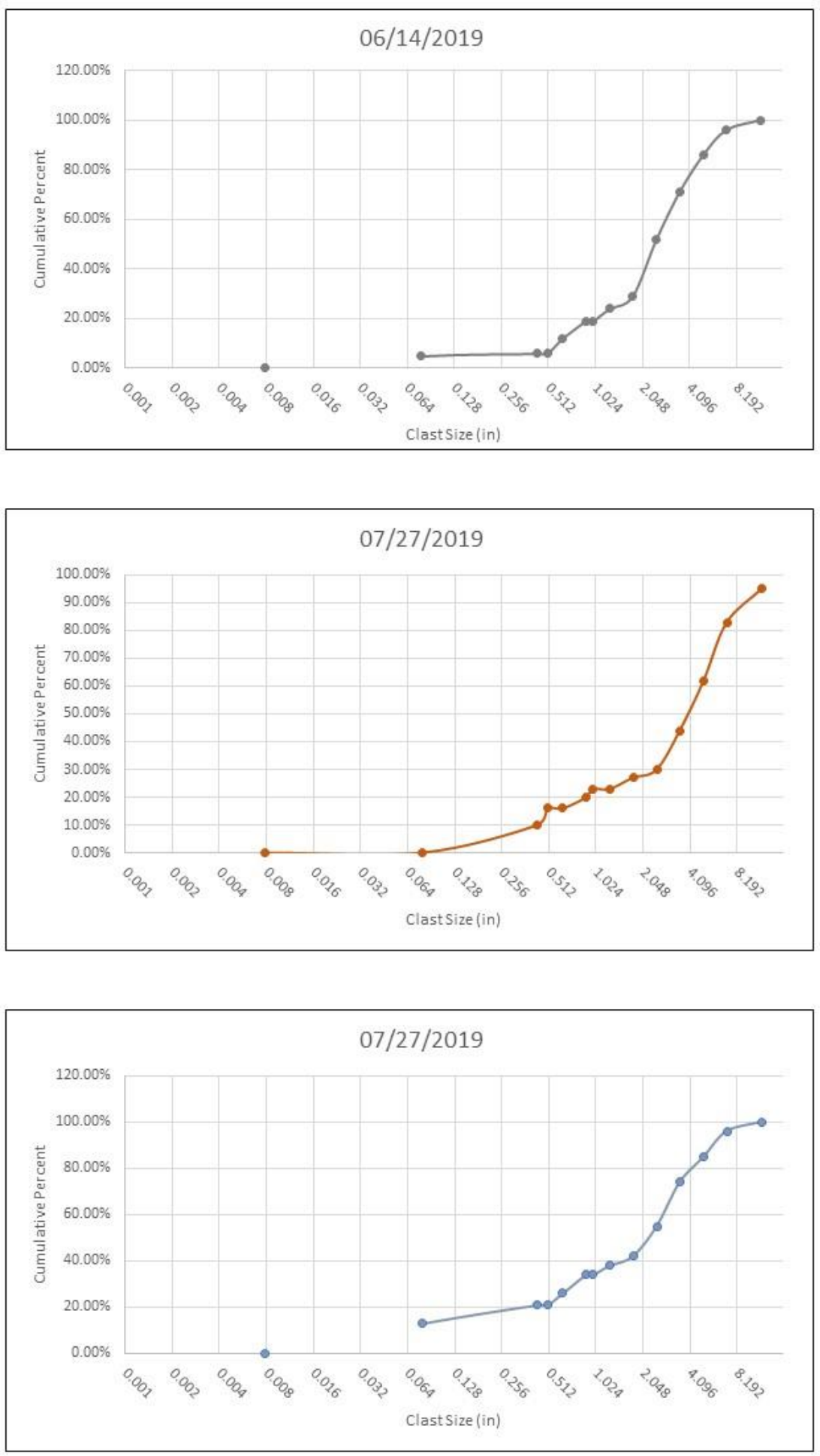

Figure 10: Cumulative probability curves for Location 3. Each of the three sampling dates for clast counts are represented. 

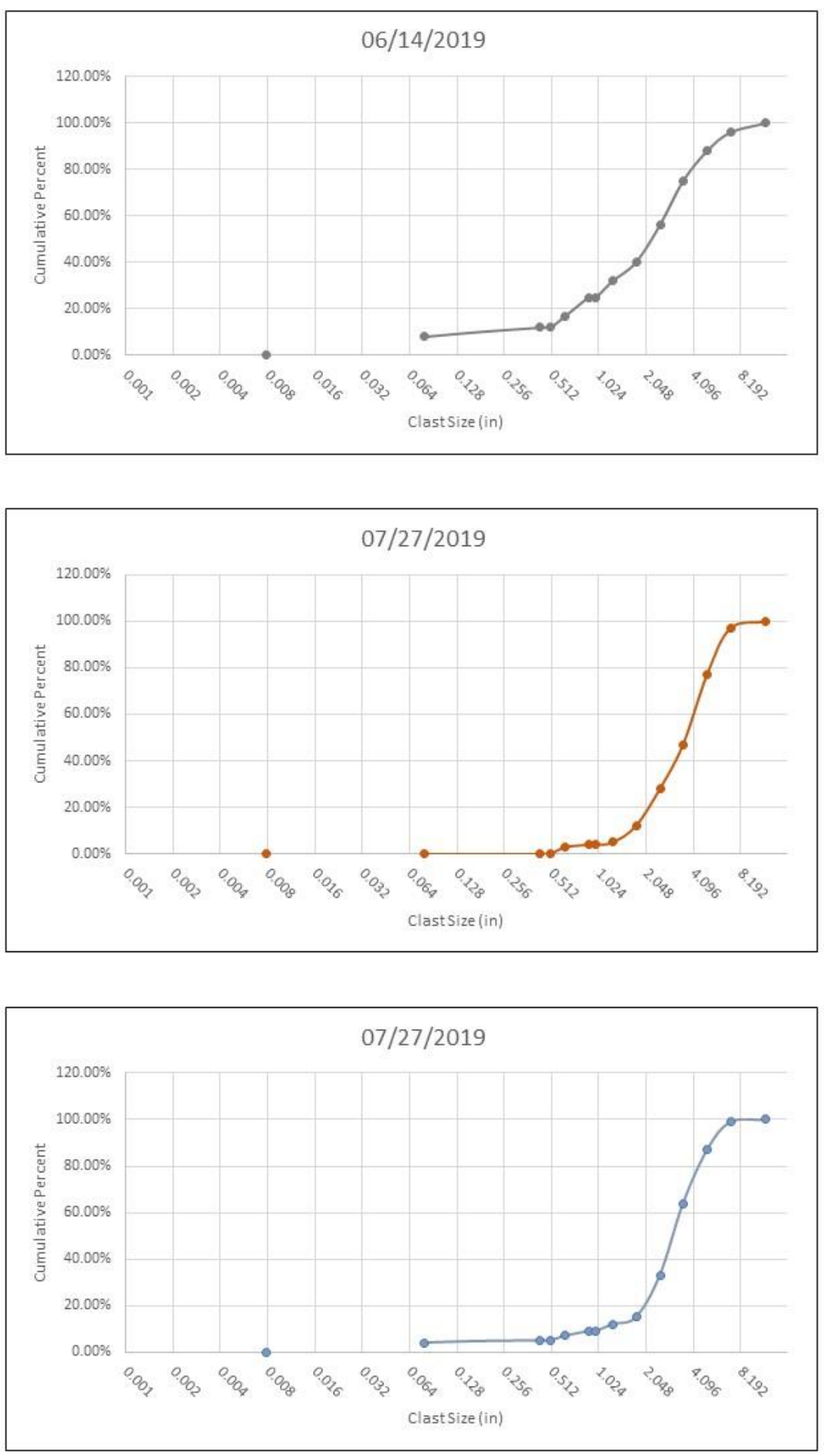

Figure 11: Cumulative probability curves for Location 4. Each of the three sampling dates for clast counts are represented. 
Table 5 depicts the discharge required to move $95 \%$ of the clast sizes in the Menominee River along with the corresponding velocity for each discharge. These values are determined using the $v_{b}$ values from the methods section. Figures 8-11 show the dispersal of clast sizes along each transect on days that 100 clasts were chosen randomly from the streambed.

At the end of the sampling season the riverbed was searched to locate painted tracer clasts. This was done by walking the length of the river and searching the stream area up to the highwater mark directly downstream from the cross-sections. Seventy of the 300 tracer clasts were located downstream from their starting transect. The remaining 230 were not located possibly because the paint was scoured off during flood events, algae growth on the rock hid the paint, or the rocks were simply passed over and not identified. It should also be noted that many of the painted rocks were found in their original positions along the stream transect and were considered un-moved. Out of the 70 painted clasts found, 26 of these clasts were moved downstream from their original location along the stream transect. The painted rocks that were found prior to major rain events were located several inches to feet downstream. Painted rocks found after the major rain events during the field season were found several yards downstream (Table 6 and 7, Figure 12).

\begin{tabular}{|c|c|c|c|c|}
\hline Location & $\mathbf{0 6 / 1 4 / 2 0 1 9}$ & $\mathbf{0 7 / 2 7 / 2 0 1 9}$ & $\mathbf{0 9 / 0 1 / 2 0 1 9}$ & $\mathbf{1 0 / 1 9 / 2 0 1 9}$ \\
\hline 1 & 1 & 10 & 10 & 2 \\
\hline 2 & 0 & 10 & 5 & 1 \\
\hline 4 & 0 & 19 & 7 & 5 \\
\hline
\end{tabular}

Table 6: Total number of painted tracer clasts found during each sampling event. These clasts were found at or downstream of their starting transect. Location 3 did not have painted clasts present. 


\begin{tabular}{|c|c|c|c|c|c|}
\hline Transect & Date Found & $\begin{array}{c}\text { Size } \\
\text { (inch) }\end{array}$ & $\begin{array}{c}\text { Velocity to } \\
\text { Move (ft/s) }\end{array}$ & $\begin{array}{c}\text { Max Potential } \\
\text { Velocity } \\
\text { (ft/s) }\end{array}$ & $\begin{array}{c}\text { Distance } \\
\text { Displaced (feet) }\end{array}$ \\
\hline 1 & $10 / 19 / 2019$ & 11.81 & 11.40 & 1.997 & 14.22 \\
\hline 1 & $10 / 19 / 2019$ & 5.04 & 7.53 & 1.997 & 186.70 \\
\hline 2 & $10 / 19 / 2019$ & 2.52 & 5.37 & 0.972 & 118.14 \\
\hline 4 & $07 / 27 / 2019$ & 5.04 & 7.53 & 0.608 & 1.92 \\
\hline 4 & $07 / 27 / 2019$ & 5.04 & 7.53 & 0.608 & 3.25 \\
\hline 4 & $07 / 27 / 2019$ & 2.52 & 5.37 & 0.608 & 0.92 \\
\hline 4 & $07 / 27 / 2019$ & 3.54 & 6.34 & 0.608 & 0.50 \\
\hline 4 & $07 / 27 / 2019$ & 5.04 & 7.53 & 0.608 & 2.00 \\
\hline 4 & $07 / 27 / 2019$ & 7.09 & 8.89 & 0.608 & 1.25 \\
\hline 4 & $07 / 27 / 2019$ & 5.04 & 7.53 & 0.608 & 0.92 \\
\hline 4 & $07 / 27 / 2019$ & 3.54 & 6.34 & 0.608 & 0.58 \\
\hline 4 & $07 / 27 / 2019$ & 5.04 & 7.53 & 0.608 & 3.33 \\
\hline 4 & $07 / 27 / 2019$ & 5.04 & 7.53 & 0.608 & 2.83 \\
\hline 4 & $07 / 27 / 2019$ & 5.04 & 7.53 & 0.608 & 3.29 \\
\hline 4 & $07 / 27 / 2019$ & 2.52 & 5.37 & 0.608 & 1.00 \\
\hline 4 & $09 / 01 / 2019$ & 5.04 & 7.53 & 0.593 & 2.00 \\
\hline 4 & $09 / 01 / 2019$ & 3.54 & 6.34 & 0.593 & 2.75 \\
\hline 4 & $09 / 01 / 2019$ & 7.09 & 8.89 & 0.593 & 1.42 \\
\hline 4 & $09 / 01 / 2019$ & 5.04 & 7.53 & 0.593 & 1.46 \\
\hline 4 & $09 / 01 / 2019$ & 3.54 & 6.34 & 0.593 & 1.08 \\
\hline 4 & $09 / 01 / 2019$ & 5.04 & 7.53 & 0.593 & 3.33 \\
\hline 4 & $10 / 19 / 2019$ & 3.54 & 6.34 & 2.370 & 1.94 \\
\hline 4 & $10 / 19 / 2019$ & 3.54 & 6.34 & 2.370 & 14.28 \\
\hline 4 & $10 / 19 / 2019$ & 3.54 & 6.34 & 2.370 & 108.56 \\
\hline 4 & $10 / 19 / 2019$ & 3.54 & 6.34 & 2.370 & 115.46 \\
\hline
\end{tabular}

Table 7: Date found and distance traveled of tracer clasts displaced from their starting location. The velocity to move column was calculated using the D95 method. The max potential velocity column was determined using the Manning's equation for the corresponding event. 


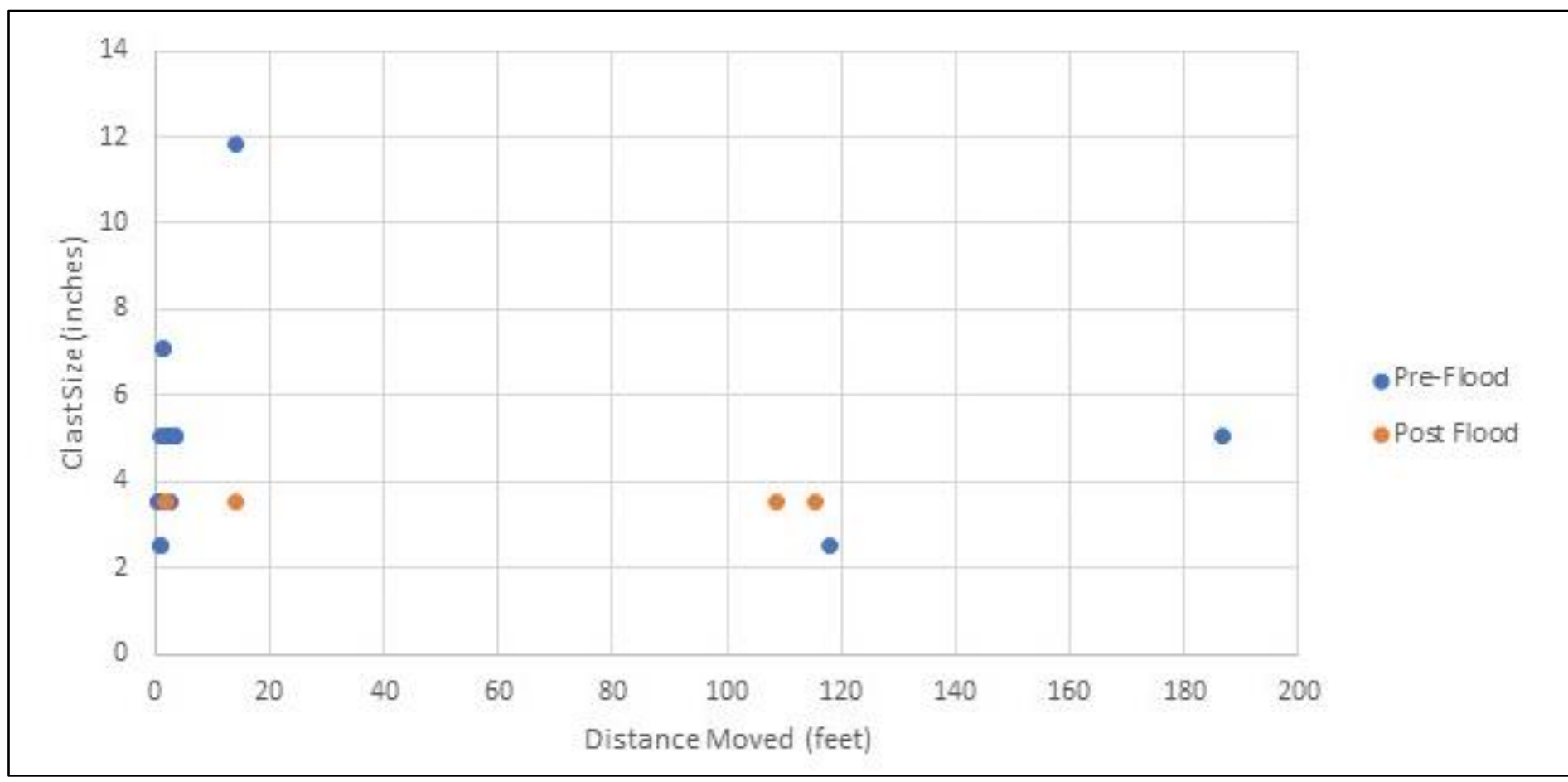

Figure 12: Distance moved versus the clast size, from clasts in Table 7 . The figure is indicating the displacement of the clasts versus their size, in addition to differentiating between the clasts found before and after flood events. 


\section{CHAPTER IV: DISCUSSION}

The purpose of this research was to better understand how a modern river system reacts to highwater flood events caused by large or frequent precipitation events. Due to the recent developments in the surrounding property it is likely that faster more aggressive runoff occurs into the Menominee River. The more aggressive runoff causes more particles and clasts to move downstream into the Mississippi. The river has natural clasts ranging from sizes of 0 inches to 11.8 inches, and in some locations, there are larger human-made clasts present. After conducting fieldwork and data analysis, it was found that $95 \%$ of the clast sizes present in the stream could have moved when water was traveling at a velocity greater than $8 \mathrm{ft} / \mathrm{s}$. This was evident by the painted tracer clasts that were found downstream from their starting locations and the D95 calculated velocity to move these size clasts. The larger human-made clasts that did move during the sampling period were not included in clast counts due to their anthropogenic origin. The clast sizes that moved through the river at these velocities were found to have an average diameter of 7.093 inches; this is the average of the clasts that moved for all four sample sites along the river. The velocity required to move the average clast size in the Menominee River is $8.891 \mathrm{ft} / \mathrm{s}$. If this velocity is met $95 \%$ of the clasts, or the average D95 clast size, from all four transects at sampling will have the potential to move downstream.

In order to address the accuracy of the D95 method values calculated from Menominee River data are compared to the data collected from a stream gauge on the Sinsinawa River. The Sinsinawa River lies 5.5 miles east of the Menominee River in Illinois and is continuously monitored by the USGS stream gauge 05414820. This river is a similar size, flows in the same direction, and is surrounded by similar land cover as the Menominee River. Both rivers also undergo similar reactions to rain events and can be used to make comparisons on local stream 
discharges to rain events. This is determined by field measurements and data from the USGS 05414820 stream gauge on the Sinsinawa River, which continually monitors the rivers conditions. In this study, the Sinsinawa River has similar trends in discharge following recharge events. This is determined by the reaction of both streams following rain events (Table 8). Baseflow discharge measurements for the Menominee River were measured at or and around $49 \mathrm{ft}^{3} / \mathrm{s}$. When compared to the Sinsinawa River's baseflow discharge, around $98 \mathrm{ft}^{3} / \mathrm{s}$. The difference in baseflow discharge between the two rivers is $49 \mathrm{ft}^{3} / \mathrm{s}$, this difference is determined from the USGS stream gauge on the Sinsinawa River. While the discharges do differ the reaction to recharge is where similarities occur.

\begin{tabular}{|c|c|c|c|c|c|}
\hline Sampling Date & $\begin{array}{c}\text { Sinsinawa } \\
\text { Discharge } \mathrm{ft}^{3} / \mathrm{s} \\
\text { At Sampling }\end{array}$ & $\begin{array}{c}\text { Sinsinawa } \\
\text { Height (ft) } \\
\text { At Sampling }\end{array}$ & $\begin{array}{c}\text { Menominee } \\
\text { Discharge } \\
\mathrm{ft}^{3} / \mathrm{s}\end{array}$ & $\begin{array}{l}\text { Observed } \\
\text { Precipitation } \\
\text { (inch) }\end{array}$ & Rain Event \\
\hline $6 / 14 / 2019$ & 35 & 4.80 & 38.0 & 0.230 & $6 / 13 / 2019$ \\
\hline $7 / 27 / 2019$ & 29 & 4.70 & 18.5 & 1.10 & $7 / 19 / 2019$ \\
\hline $9 / 1 / 2019$ & 27 & 4.60 & 15.7 & 0.180 & $8 / 21 / 2019$ \\
\hline $9 / 12-13 / 2019$ & $7500 *$ & $12.0^{*}$ & $\begin{array}{c}2180^{* *} \\
505.1^{* * *} \\
\end{array}$ & 2.41 & 9/12/2019 \\
\hline $9 / 15 / 2019$ & 75 & 5.20 & 75.9 & 2.41 & $9 / 12 / 2019$ \\
\hline 10/5-7/2019 & $850 *$ & $7.80^{*}$ & $\begin{array}{c}1142^{* *} \\
260.8^{* * *}\end{array}$ & 0.580 & $10 / 6 / 2019$ \\
\hline $10 / 19 / 2019$ & 89 & 5.30 & 41.2 & 0.580 & $10 / 6 / 2019$ \\
\hline
\end{tabular}

Table 8: Discharge and stream height values for the Sinsinawa and Menominee Rivers. The Menominee River discharge data used is from Location 1. This table indicates the values at the time of sampling and directly after major rain events. Values marked with $(*)$ indicate the highest values collected during the flood event by the USGS gauge station. Values marked with $(* *)$ are the calculated flood discharge values using the D95, $v_{b}$ velocity at Location 1. Values with (***) are the Manning's equation calculated discharge. Shaded values indicate measurements at the time of the rain events (NOAA, 2020). 
Following the September $12^{\text {th }}$ rain event, floods were recorded in the area surrounding the streams. Measurements were taken on September $15^{\text {th }}$ in the field at the Menominee River field site. The Menominee River reached an observed discharge of $75.9 \mathrm{ft}^{3} / \mathrm{s}$ on September $15^{\text {th }}$ when field data were collected, but likely exceeded this discharge, evident by highwater stains above the stream's banks. Following this event, the USGS stream gauge on the Sinsinawa River registered a discharge of $7500 \mathrm{ft}^{3} / \mathrm{s}$ during the rain event and had a discharge of $75 \mathrm{ft}^{3} / \mathrm{s}$ on September 15th. During the September $12^{\text {th }}$ event the Menominee River's discharge was $96.5 \%$ greater than it's baseflow discharge based on the data from September $15^{\text {th }}$ and the Manning's equation calculation for the flood event calculation. The flood discharge of the Sinsinawa River was $99.8 \%$ greater than the base flow on September $12^{\text {th }}$

In addition to the September $12^{\text {th }}$ rain event a second event was recorded on October $6^{\text {th }}$. The Menominee River's discharge from this event was recorded on October $19^{\text {th }}$ and measured $41.2 \mathrm{ft}^{3} / \mathrm{s}$ but showed signs of a greater discharge evident by highwater staining above the river's banks. The discharge for this flood event was calculated at $96.4 \%$ greater than the baseflow on October $19^{\text {th }}$. The Sinsinawa's discharge from this event measured $850 \mathrm{ft}^{3} / \mathrm{s}$ during the rain event and $89 \mathrm{ft}^{3} / \mathrm{s}$ following the event on October 19 th. The October $6^{\text {th }}$ event resulted in a discharge 89.53\% greater than the baseflow discharge based on the data from October $19^{\text {th }}$ (Table 8 ).

The real-time flood data from the Sinsinawa River (Table 8) cannot directly be compared to the Menominee River since Menominee River could not be measured at the peak of the flood events without a gauge. This means that highwater values for the Menominee River during this event are estimations based on highwater stains and D95 velocity values in the Manning's equation. These values are greater than the values from the sampling events following the initial rain event, but likely are lower than the actual flood values due to estimations used. It is likely 
for these events that the Menominee River reacted in a similar fashion to the Sinsinawa, though this cannot be said for certain due to the lack of real time flood data.

The estimated discharge for these flood events was calculated using Manning's equation and is compared to bank-full data (Table 9). When comparing the Manning's values to the D95 discharge and velocity values, the estimated highwater values are lower than the D95 calculated values. This may be due to the variables used in the Manning's equation to estimate the discharge and velocity of flood events (Table 10).

\begin{tabular}{|c|c|c|c|}
\hline Location & $\begin{array}{c}\text { Sampling } \\
\text { Date }\end{array}$ & $\begin{array}{c}\text { Estimated } \\
\text { Velocity (ft/s) }\end{array}$ & $\begin{array}{c}\text { Estimated } \\
\text { Discharge }(\mathbf{f t} / \mathbf{s})\end{array}$ \\
\hline 1 & $09 / 15 / 2020$ & 1.299 & 55.802 \\
\hline $1^{*}$ & $09 / 15 / 2020^{*}$ & $2.025^{*}$ & $504.940^{*}$ \\
\hline 1 & $10 / 19 / 2020$ & 1.249 & 45.157 \\
\hline $1^{*}$ & $10 / 19 / 2020^{*}$ & $1.997^{*}$ & $260.849^{*}$ \\
\hline 2 & $09 / 15 / 2020$ & 0.612 & 54.534 \\
\hline $2^{*}$ & $09 / 15 / 2020^{*}$ & $0.976^{*}$ & $251.604^{*}$ \\
\hline 2 & $10 / 19 / 2020$ & 0.592 & 43.829 \\
\hline $2^{*}$ & $10 / 19 / 2020^{*}$ & $0.972^{*}$ & $230.392^{*}$ \\
\hline 3 & $09 / 15 / 2020$ & 0.335 & 15.148 \\
\hline $3^{*}$ & $09 / 15 / 2020^{*}$ & $0.433^{*}$ & $66.130^{*}$ \\
\hline 4 & $09 / 15 / 2020$ & 0.914 & 19.131 \\
\hline $4^{*}$ & $09 / 15 / 2020^{*}$ & $1.536^{*}$ & $292.242^{*}$ \\
\hline 4 & $10 / 19 / 2020$ & 1.430 & 28.781 \\
\hline $4^{*}$ & $10 / 19 / 2020^{*}$ & $2.370^{*}$ & $175.574^{*}$ \\
\hline
\end{tabular}

Table 9: Velocity and discharge of flood events based on Manning's equation. Values with (*) are the Manning's equation estimated flood values, and values without $(*)$ are bank-full data. Location 4 values were calculated using Location 3's slope due to the Location 4's slope equaling zero. 


\begin{tabular}{|c|c|c|c|c|}
\hline Location & $\begin{array}{c}\text { Manning's } \\
\text { Coefficient (n) }\end{array}$ & $\begin{array}{c}\text { Highwater } \\
\text { Hydraulic Radius } \\
\mathbf{0 9 / 1 5 / 2 0 1 9}\end{array}$ & $\begin{array}{c}\text { Highwater } \\
\text { Hydraulic Radius } \\
\mathbf{1 0 / 1 9 / 2 0 1 9}\end{array}$ & $\begin{array}{c}\text { Streambed } \\
\text { Slope }\end{array}$ \\
\hline 1 & 0.104 & 1.414 & 1.385 & 0.013 \\
\hline 2 & 0.100 & 1.433 & 1.424 & 0.003 \\
\hline 3 & 0.392 & 0.992 & $\mathrm{~N} / \mathrm{D}$ & 0.013 \\
\hline 4 & 0.120 & 1.191 & 1.111 & $0.013^{*}$ \\
\hline
\end{tabular}

Table 10: Manning's equation variable values. These values were used for highwater velocity and discharge calculations. The $(*)$ in Location 4's data is due to the slope for Location 3 being used to complete Location 4's calculations. The measured slope for Location 4 was zero, likely due to the accuracy of equipment.

During the largest two rain events the Menominee River was observed exceeding its banks with a highwater bank to bank distance of $77 \mathrm{ft}$. This was identified by highwater debris stains in the cow pasture surrounding the stream at Location 1. Downstream the other field locations showed similar signs of highwater staining, in addition to scour marks from tree limbs and rocks moving downstream (Figure 12 and 13). These scour marks indicate that large objects were moving downstream outside of the active stream channel. Additionally, debris such as fallen trees and tree limbs were scattered outside of the stream in some locations. This debris was not present until after the large recharge events. The extent of scour marks and debris indicate a dramatic flood event that had the strength to move large debris downstream. In addition to the debris moving downstream as a result of increased flow, it is likely that the stream's ability to erode was heightened. After this major flood event a bank collapse was also noted at Location 4, this was indicated by un-vegetated soil on the west bank of the stream. 


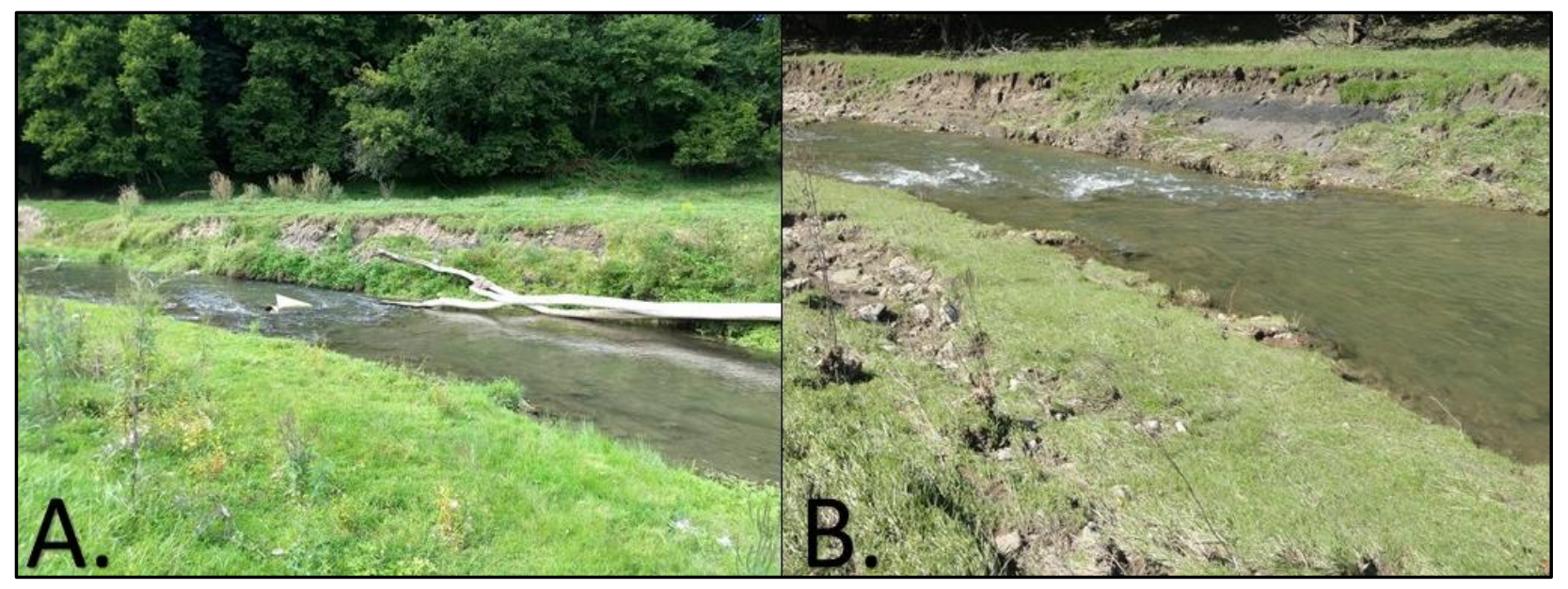

Figure 13: Location 1 at the beginning of sampling on 06/14/2019 (A.), and at the end of sampling on 10/19/2019 (B.). These images show changes to the stream bank, bent over vegetation, and a tree that was moved downstream during flooding.

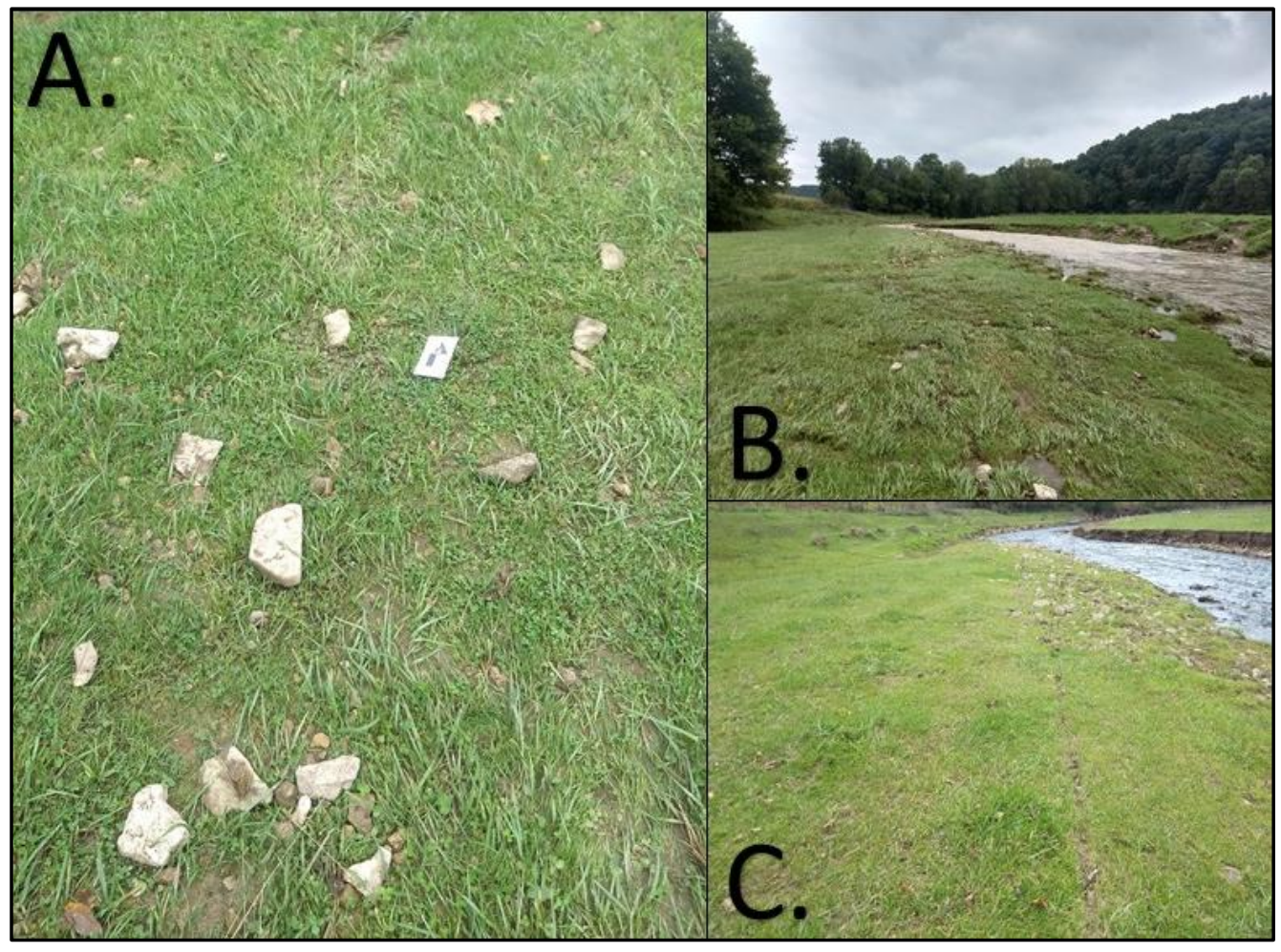

Figure 14: Highwater marks and changes to the area surrounding the stream. A. shows clasts that were deposited on the banks of the river during flooding. Note the grass is bent in the direction of flow. B. Shows highwater staining and clasts deposited during flooding. C. Shows scrapes and bent over grass. This is the result of debris being dragged along the bank during flooding. 
Downstream of the study area human made concrete blocks approximately $6 \mathrm{ft}$ by $3 \mathrm{ft}$ by $3 \mathrm{ft}$ were toppled during the final rain and flood events. These blocks were laid along the banks of the river, downstream of the field site, to prevent erosion of the adjacent agricultural fields. When compared to the D95 clast size, these blocks exceed the average diameter of $95 \%$ of the clasts present in the stream. The human made blocks have a diameter of 3 feet or 36 inches compared to the D95 average of 7.093 inches. This location was left out of the study area due to anthropogenic changes to the stream bed and bank. While these blocks were not used as tracers due to their unnatural nature and location, they can be used to gauge the overall strength of the stream when flowing at bank-full or flood stages. It is possible that the stream can move larger clast sizes similar to these manmade blocks, but clasts of this size do not naturally occur regularly in the stream. This means that estimates of the stream's overall strength may be lower than what the actual value may be due to the absence of these larger clast sizes. The largest natural clast found in the stream was 11.8 inches in diameter which was $32 \%$ smaller than the manmade concrete blocks. When comparing these to clast sizes and the discharge needed to move them; it was determined that the discharge required to move the concrete block was almost double the discharge required to move clasts with a diameter of 11.8 inches.

Clast movement was identified during the final three sampling events of the field season. These sampling events occurred after major rain events or multiple rain events between sampling sessions. Sampling events occurred after major rain events or multiple rain events in order to monitor the stream after or during higher rates of discharge. The final three sampling events had notable amounts of rain, which likely cause more of the clasts to be moved downstream. This suggests that these rain events produced enough recharge into the stream to create velocities capable of moving clasts up to 11.8 inches. This cannot rule out the possibility of clasts greater 
than 11.8 inches moving through the stream, as the largest tracer clast painted was 11.8 inches. Clasts larger than this were too difficult to remove and paint, therefore cannot be stated to have moved with certainty.

In order to track how far and what size clasts were moving through the stream, painted tracer clasts were used. In total, 25 painted clasts were located downstream from their original starting location along the stream transect. Location three had no painted clasts present and was only used for clast size analysis and discharge measurements. Location four likely had the most clasts found due to the nature of the stream at this site. Here the river was a shallow riffle where no algae grew, or sediment deposited over the painted clasts. This location may have lost some painted clasts as a result of burial during a bank collapse between the final two sampling events. Locations one and two were more difficult to locate clasts due to algae growth, greater depth, and sediment deposition over clasts. Based on the painted clasts that were located downstream from their corresponding transects, it was determined that clast sizes up to 11.8 inches in diameter were able to be moved down stream. Though not all painted clasts were found we are able to determine that clast sizes up to a diameter of 11.8 inches can move.

Due to the nature of the debris found downstream and the distance of the painted clasts that were found in the field it is likely that the Menominee River is capable of moving the large objects downstream in addition to the clasts present in the stream. Along with the clast and debris movement downstream, the ability of the Menominee River to erode and collapse banks suggests that the stream is capable of more erosive causing quick and drastic change to the stream bed. The data collected suggests that the Menominee River is capable of aggressive and erosive flow. 
While addressing discharge, it is important to note the decrease in discharge at Location 2 (Table 4). Upstream of this location there is an outcrop of the limestone bedrock that makes up the streambed and western bank of the river. This bedrock is comprised of carbonate rocks of the Galena and Platteville Groups, which are known to contain karst features because this region is one of the five main karst zones found in Illinois (Panno, 2015). The karst features in this bedrock provide a secondary porosity for aquifers, these karst features are observed in outcrops, roadcuts and quarries (Panno, 2015). In the surficial setting at the Menominee River field site it is possible that upstream of Location 2 there are karst features in the bedrock composing the stream bed. These karst features below the streambed may provide recharge pathways into subsurface aquifers, causing a loss of water from the active stream channel (Panno, 2017). Due to the river's increase in discharge at Location 3, the stream is being recharged at some point by another unidentified feature. Additionally, the nearby urban runoff from the subdivision contributed to the stream between locations 1 and 2 may not be playing a role as first expected in the increased flow to the Menominee River during storm events. While the rate at which water is leaving through karst features is uncertain, it is possible the loss to karst is greater or the same as what may be recharged into the stream through runoff specifically from the surrounding land development. 


\section{CHAPTER V: CONCLUSION}

During the sampling period the Menominee River underwent two major rain events that resulted in the river flooding its banks. These floods exceeded the banks of the river and moved various debris downstream, including the painted tracer clasts and humanmade concrete blocks. While these two items were used to observe movement downstream, it is likely non-painted clasts and other material of similar sizes moved downstream. By using the collected data in the Manning's equation, it was estimated that the flood discharge may have reached 504. ft3/s. When compared to the D95 discharge and the discharge using the D95 method to move the humanmade concrete blocks, the flood discharge using Manning's equation is substantially lower. It is likely the actual highwater discharge was closer to the calculated discharge to move the humanmade concrete blocks, with a max of $5056 \mathrm{ft}^{3} / \mathrm{s}$. The differences between the Manning's and $v_{b}$ calculations may be a result of errors during the data collection process. In particular, the determination of the wetted perimeter and hydraulic radius may have provided room for error. This is due to the number of data points collected along the cross-section transects. A lager number of points would provide a more exact measurement of the crosssection. Additionally, the D95 method used may not be an accurate representation of the clasts that move in the stream. The D95 method is often used in mountain streams with larger slopes than that of the Menominee River. This may have provided a source of error in the $v_{b}$ equation due to the use of the clast size determined from D95. These differences may result in an overestimation of the values for the Menominee River.

The modern stream system of the Menominee River indicates that it is strong enough to move clasts up to 11.8 inches in diameter downstream during or after recharge events. We couldn't track which specific recharge events moved each particular clast size. It is apparent that 
within one sampling season, June through September, clast movement does occur as a result of increased discharge within the stream. The identified clast movement only accounts for clasts available within the Menominee River. It is possible that the estimates for the largest clast size moving downstream is an underestimate. This is due to low number of clasts larger than 11.8 inches in diameter. It is evident the stream is capable of moving larger clasts based on the movement of manmade concrete blocks present downstream of Location 4. However, a clear indication of what the maximum clast size moving downstream cannot be determined due to the rarity of clasts greater than 11.8 inches in diameter. Additionally, we are unable to accurately identify the discharge immediately following recharge events. This is due to the risk of entering the Menominee River during highwater flow and the lack of a permanent stream gauge. Identifying the true highwater velocities and highwater discharge would provide a more concise picture of the strength of the stream.

When compared to the Sinsinawa River, the Menominee River reacts in a similar fashion following recharge events. This is evident when highwater data from the Sinsinawa stream gauge are compared to field data collected after rain events. Because these two streams react in a similar fashion the discharge recorded from the Sinsinawa River gauge can be used to determine the size clasts moving through the stream and the potential to move larger clast sizes. In order to better understand the Menominee River future work studying sediment movement withing the stream and movement of clasts into the stream may be useful to determine the amount of sediment moving during baseflow. Additionally, larger tracer clasts could be used to determine what the largest clast size is to move through the stream. This will provide more information about the dynamics of the stream during highwater events and at baseflow. Further research can be conducted to monitor the effects of urban surfaces on runoff into the stream. 
Urban surfaces provide quicker pathways for runoff into the stream, which may cause more aggressive flow. A model could be used to predict the amount and rate of runoff entering the Menominee River due to urban surfaces as well as predict the impact of karst on the Menominee River. The impacts of karst on this system are another avenue for better understanding this stream and others in the region. Conducting further research on the Menominee River may provide a better understanding of the modern river system, specifically those within a karst system with urban surfaces surrounding them.

Ultimately, sedimentation becomes an issue for downstream locations, in this case the Mississippi River. Increased rates of sedimentation can pose problems in the form of frequent flooding events, loss of land upstream, and more aggressive and erosive flow. Monitoring rivers for increased sedimentation rates can assist in the development in positive land-use practices and soil retention. 


\section{WORKS CITED}

Alexander, R.B., Smith, R.A., Schwarz, G.E., Boyer, E.W., Nolan, J.V., and Brakebill, J.W., 2008, Differences in Phosphorus and Nitrogen Delivery to The Gulf of Mexico from the Mississippi River Basin: Environmental Science \& Technology, v. 42, p. 822-830, doi: $10.1021 /$ es0716103.

Arnold, J., Srinivasan, R., Muttiah, R., and Williams, J.R.. (1998). Large Area Hydrologic Modeling and Assessment Part I: Model Development. JAWRA Journal of the American Water Resources Association. V. 34. p. 73 - 89, doi: 10.1111/j.17521688.1998.tb05961.x.

Bernhardt, E.S., Band, L.E., Walsh, C.J., and Berke, P.E., 2008, Understanding, Managing, and Minimizing Urban Impacts on Surface Water Nitrogen Loading: Annals of the New York Academy of Sciences, v. 1134, p. 61-96, doi: 10.1196/annals.1439.014.

Booth, Derek. (1991). Urbanization and the Natural Drainage System - Impacts, Solutions, and Prognoses. Northwest Environmental Journal. 7. 93-118.

Craddock, M., 2016, May. Protocols for Measuring Water Level and Streamflow. National Water Quality Monitoring Conference Field Protocols Workshop. Massachusetts.

Goode, J.R., and Wohl, E., 2010, Coarse sediment transport in a bedrock channel with complex bed topography: Water Resources Research, v. 46, doi: 10.1029/2009wr008135.

James, L.A., 2013, Legacy sediment: Definitions and processes of episodically produced anthropogenic sediment: Anthropocene, v. 2, p. 16-26, doi: 10.1016/j. ancene.2013.04.001. 
Knox, J.C., 1985, Responses of Floods to Holocene Climatic Change in the Upper Mississippi Valley: Quaternary Research, v. 23, p. 287-300, doi: 10.1016/0033-5894(85)90036-5.

Knox, J.C., 2001, Agricultural influence on landscape sensitivity in the Upper Mississippi River Valley: Catena, v. 42, p. 193-224, doi: 10.1016/s0341-8162(00)00138-7.

Knox, J. C. (2006). Floodplain sedimentation in the Upper Mississippi Valley: Natural versus human accelerated. Geomorphology, 79(3-4), 286-310. doi:10.1016/j.geomorph.2006.06.031

Leopold, L.B., 1968, Hydrology for urban land planning - A guidebook on the hydrologic effects of urban land use: Circular, doi: 10.3133/cir554.

Miller, S. O., Ritter, D. F., Kochel, R., \& Miller, J. R. (1993). Fluvial responses to land-use changes and climatic variations within the Drury Creek watershed, southern Illinois. Geomorphology, 6(4), 309-329. doi:10.1016/0169-555x(93)90053-5

Morin, J., \& Benyamini, Y. (1977). Rainfall infiltration into bare soils. Water Resources Research, 13(5), 813-817. doi:10.1029/wr013i005p00813

National Oceanic and Atmospheric Administration, US Department of Commerce, N. (2015, May 20). Monthly Climate Graphs and Table Galena, IL. Retrieved September 7, 2020, from https://www.weather.gov/dvn/climategraph_month_image_table_mli

Neitsch, S.L., Arnold, J.G., Kinry, J.R., and Williams, J.R.. (2011). Soil and water assessment tool theoretical documentation. Version 9. 
Panno, S.V., D.E. Luman, and D.R. Kolata, 2015, Characterization of karst terrain and regional tectonics using remotely sensed data in Jo Daviess County, Illinois: Illinois State Geological Survey, Circular 589, p. 1-38, 1 map, 1:62,500, digital appendix at http://isgs.illinois.edu/publications/c589/appendix.

Panno, S.V., D.E. Luman, W.R. Kelly, T.H. Larson, and S.J. Taylor, 2017, Karst of the Driftless Area of Jo Daviess County, Illinois: Illinois State Geological Survey, Circular 586, p. $1-50$.

Reinertsen, D.L., 1992, Guide to the Geology of the Galena Area: Jo Daviess County, Illinois, Lafayette County, Wisconsin. Department of Energy and Natural Resources, Illinois State Geological Survey, Fieldtrip Guidebook No. 1992B , p. 1-56, https://archive.org/details/guidetogeol1992rein/page/n55 (accessed February 2019).

Seyoum, W.M., Milewski, A.M., and Durham, M.C., 2015, Understanding the relative impacts of natural processes and human activities on the hydrology of the Central Rift Valley lakes, East Africa: Hydrological Processes, v. 29, p. 4312-4324, doi: 10.1002/hyp.10490.

Simon, A., and Rinaldi, M., 2006, Disturbance, stream incision, and channel evolution: The roles of excess transport capacity and boundary materials in controlling channel response: Geomorphology, v. 79, p. 361-383, doi: 10.1016/j.geomorph.2006.06.037.

Storey, H.C., Hobba, R.L., Rosa, J.M., 1964. Hydrology of forest lands and rangelands. In: Chow, V.T. Ed., Ž . Handbook of Applied Hydrology. McGraw-Hill, New York, pp. 22r1-22r52 
Tomer, M. D., \& Schilling, K. E. (2009). A simple approach to distinguish land-use and climatechange effects on watershed hydrology. Journal of Hydrology, 376(1-2), 24-33. doi:10.1016/j.jhydrol.2009.07.029

United Nations. 2008. World urbanization prospects: the 2007 revision. New York: Population Division

Usinowicz, J., Qiu, J., and Kamarainen, A., 2016, Flashiness and Flooding of Two Lakes in the Upper Midwest During a Century of Urbanization and Climate Change: Ecosystems, v. 20, p. 601-615, doi: 10.1007/s10021-016-0042-7.

Walling, D., and He, Q., 1998, The spatial variability of overbank sedimentation on river floodplains: Geomorphology, v. 24, p. 209-223, doi: 10.1016/s0169-555x(98)00017-8.

Wauchope, R.D., Sumner, H.R., Truman, C.C., Johnson, A.W., Dowler, C.C., Hook, J.E., Gascho, G.J., Davis, J.G., Chandler, L.D., 1999. Runoff from a cornfield as affected by tillage and corn canopy: a large-scale simulated-rainfall hydrologic data set for model testing. Water Resources Research 35, 2881-2885

Whiting, Peter \& Stamm, John \& B. Moog, D \& L. Orndorff, R. (1999). Sediment Transporting Flows in Headwater Streams. Bulletin of the Geological Society of America. Doi: 111. 10.1130/0016-7606(1999)111<0450:STFIHS>2.3.CO;2.

Wohl, E.E., and Wilcox, A., 2005, Channel geometry of mountain streams in New Zealand: Journal of Hydrology, v. 300, p. 252-266, doi: 10.1016/j.jhydrol.2004.06.006. (n.d.). Manuscript. 


\section{APPENDIX A: SUPPLEMENTARY FIGURES}
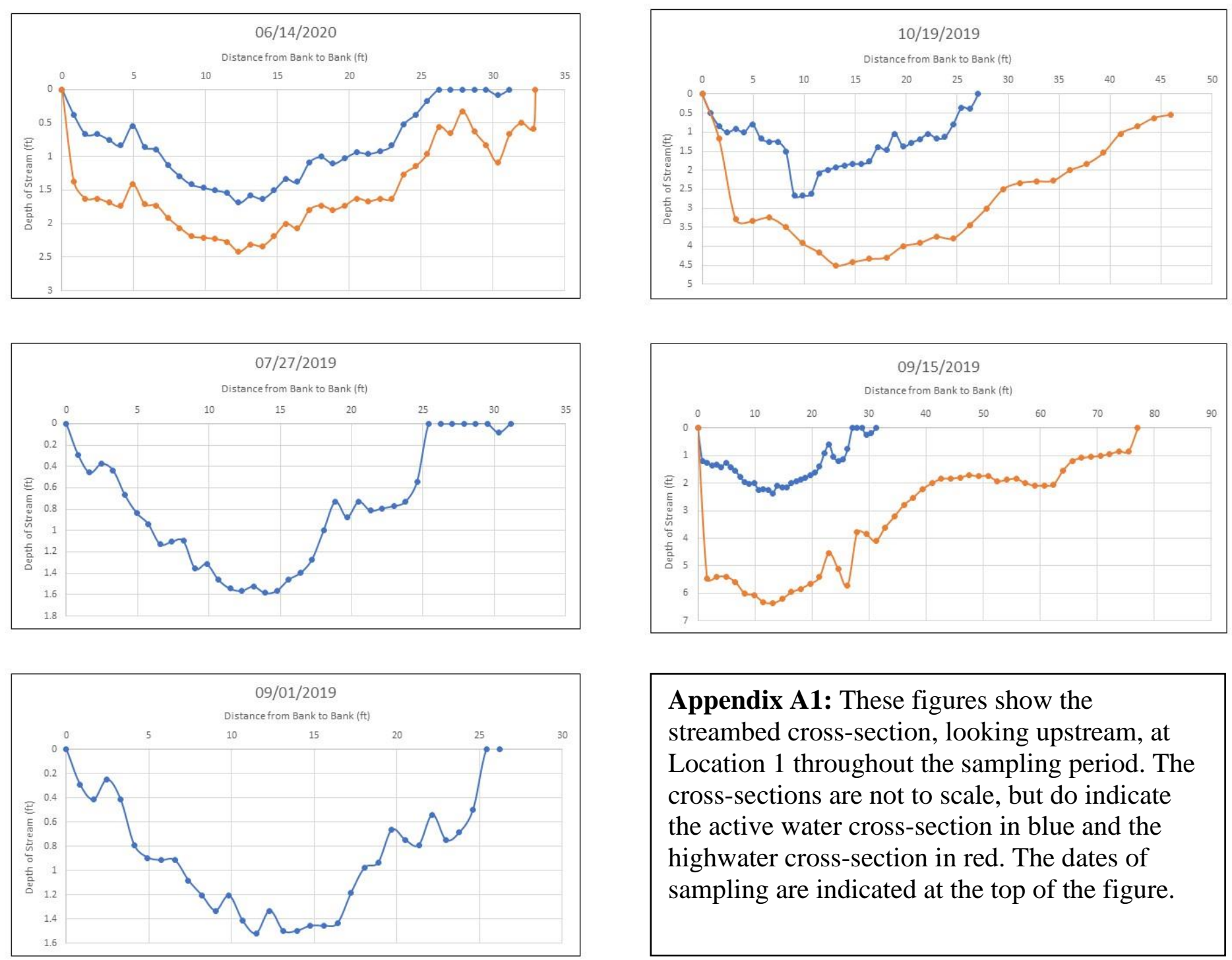

Appendix A1: These figures show the streambed cross-section, looking upstream, at Location 1 throughout the sampling period. The cross-sections are not to scale, but do indicate the active water cross-section in blue and the highwater cross-section in red. The dates of sampling are indicated at the top of the figure. 

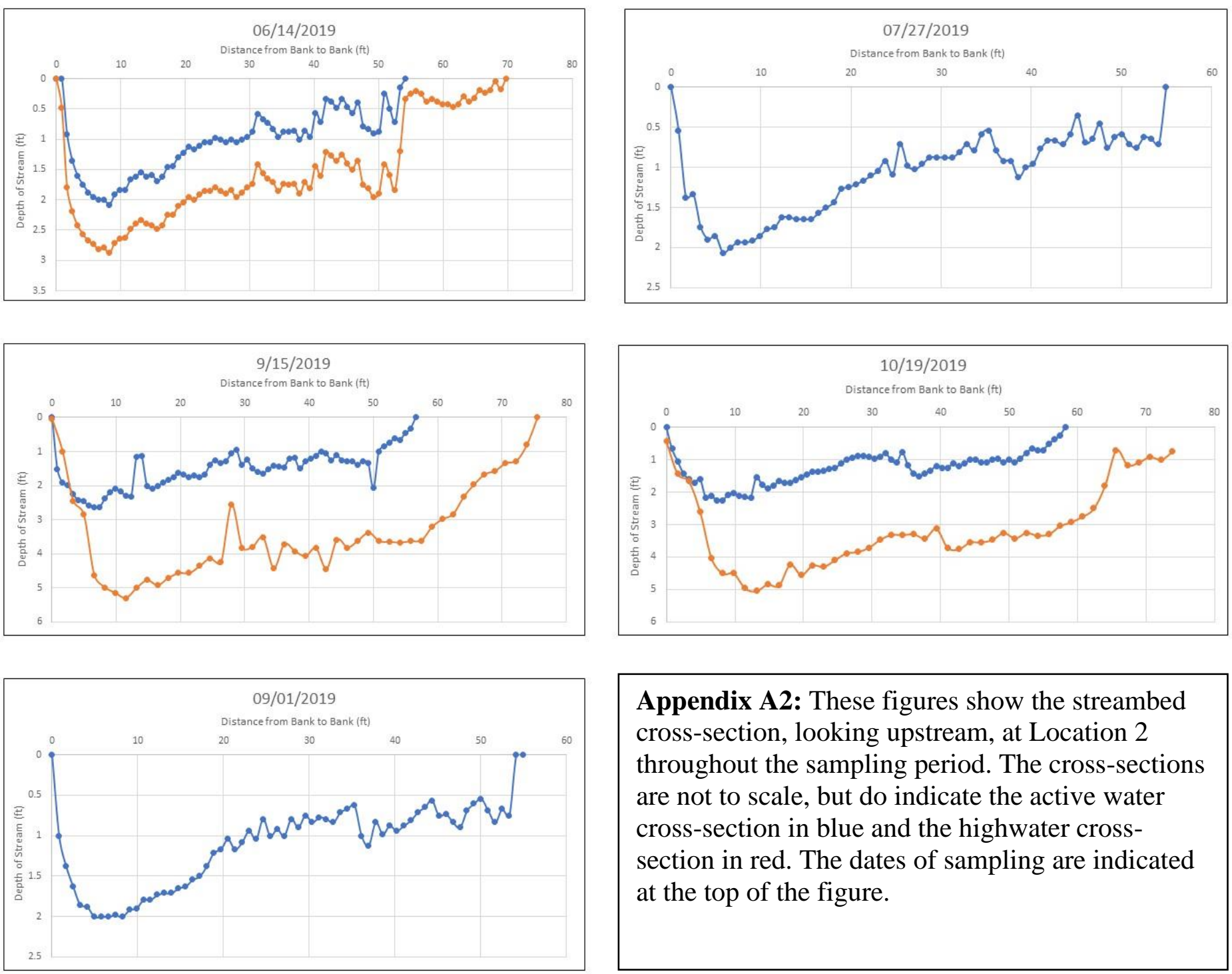

Appendix A2: These figures show the streambed cross-section, looking upstream, at Location 2 throughout the sampling period. The cross-sections are not to scale, but do indicate the active water cross-section in blue and the highwater crosssection in red. The dates of sampling are indicated at the top of the figure. 

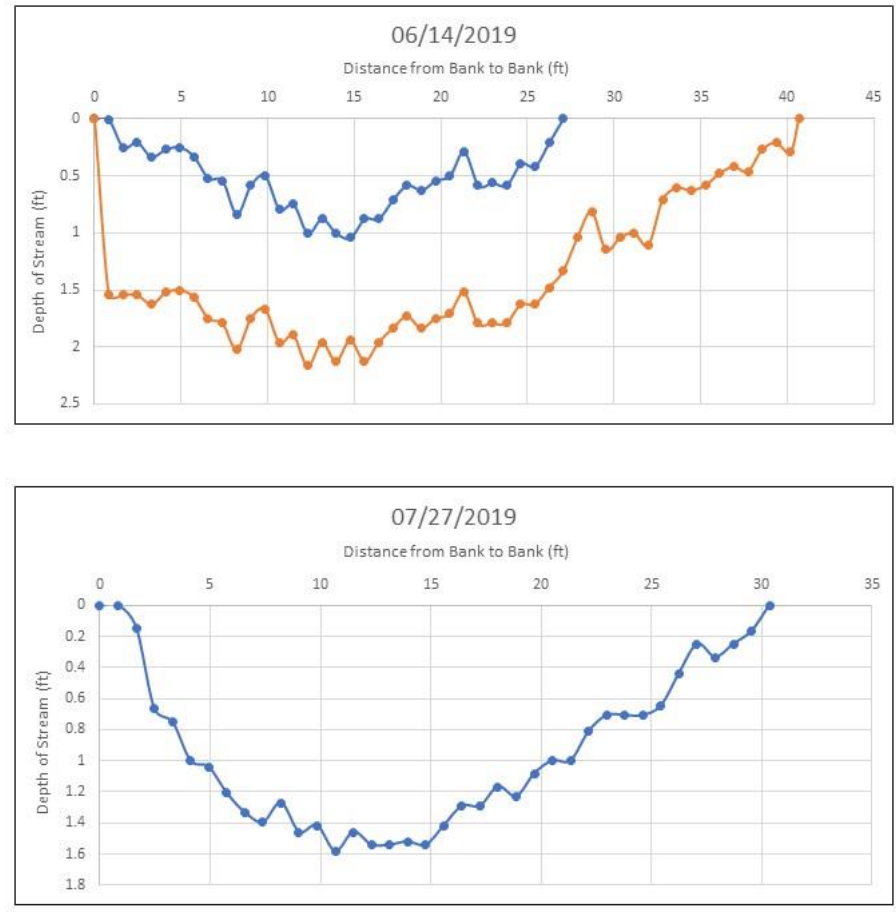

09/1/2019

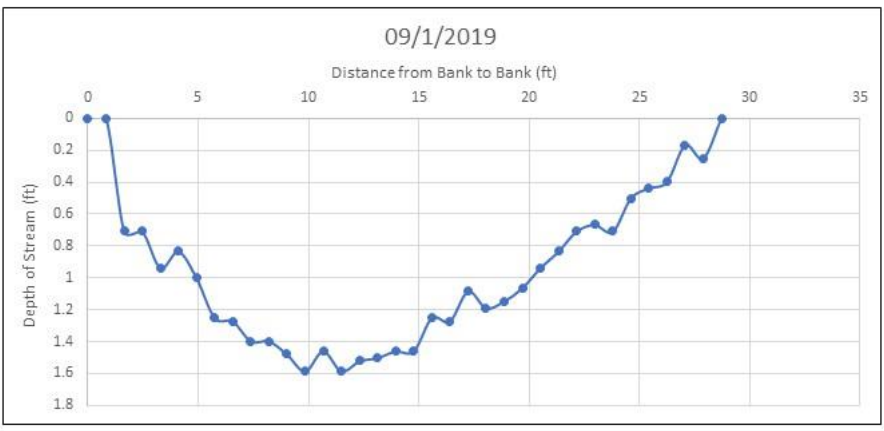

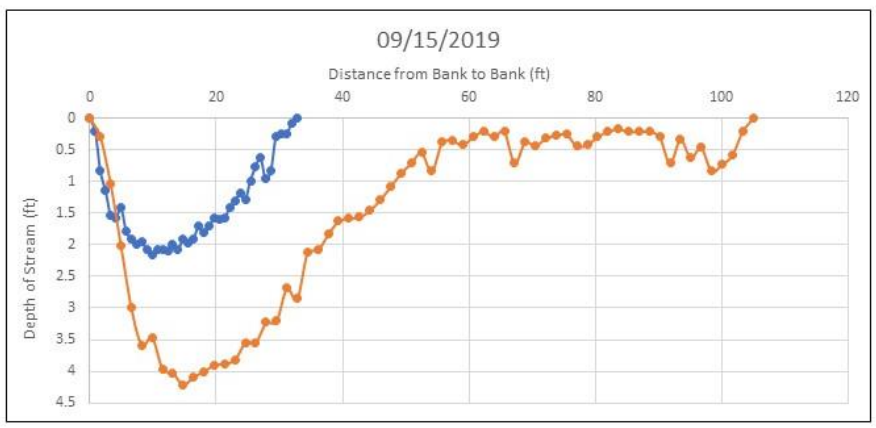

Appendix A3: These figures show the streambed cross-section, looking upstream, at Location 3 throughout the sampling period. The crosssections are not to scale, but do indicate the active water cross-section in blue and the highwater cross-section in red. The dates of sampling are indicated at the top of the figure. 

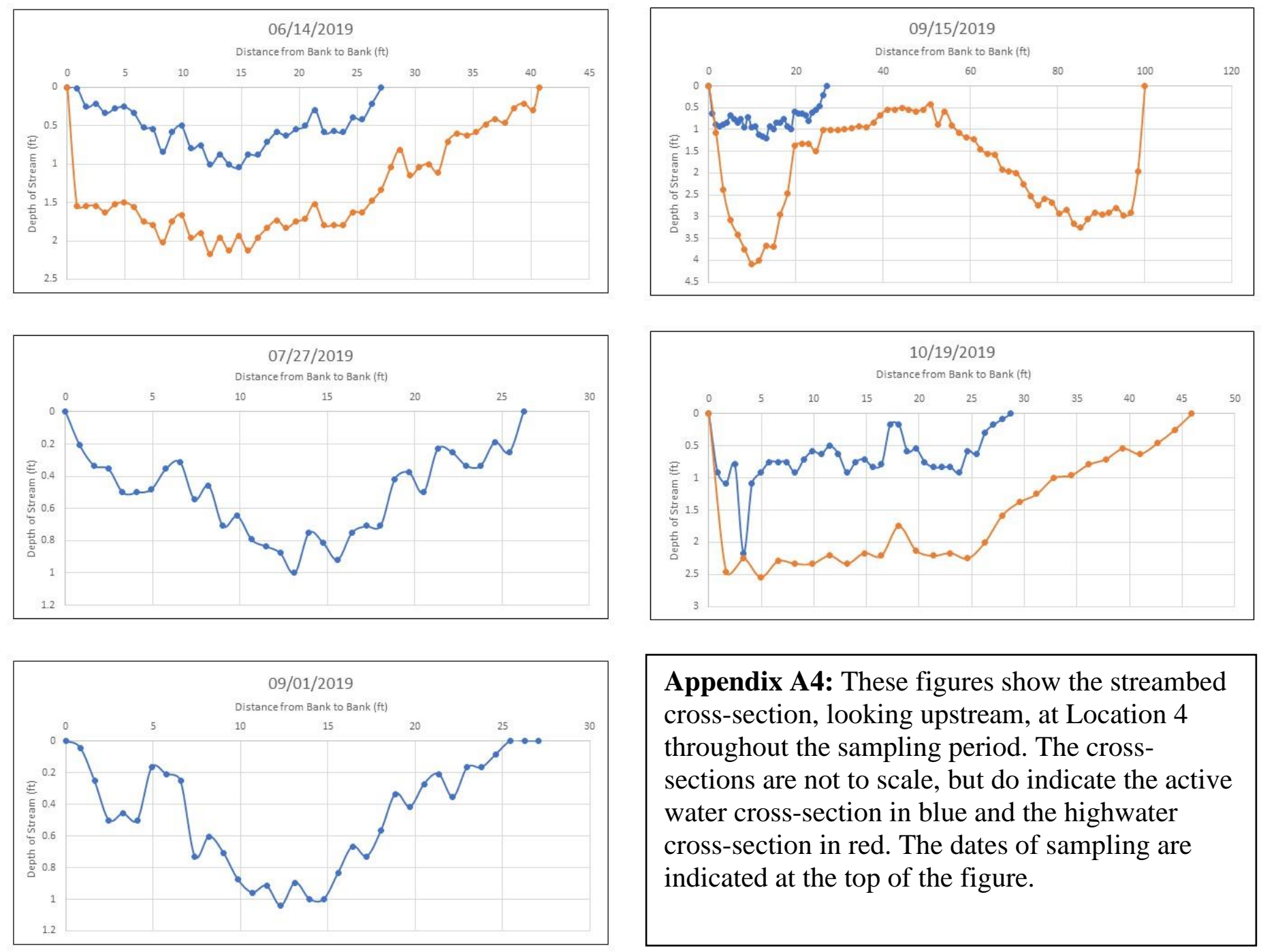

Appendix A4: These figures show the streambed cross-section, looking upstream, at Location 4 throughout the sampling period. The crosssections are not to scale, but do indicate the active water cross-section in blue and the highwater cross-section in red. The dates of sampling are indicated at the top of the figure. 